\title{
Process monitoring for material extrusion additive manufacturing: a state-of-the-art review
}

\author{
Alexander Oleff $^{1} \mathbb{D} \cdot$ Benjamin Küster $^{1} \cdot$ Malte Stonis $^{1} \cdot$ Ludger Overmeyer $^{2}$
}

Received: 22 February 2021 / Accepted: 30 April 2021 / Published online: 19 May 2021

(c) The Author(s) 2021

\begin{abstract}
Qualitative uncertainties are a key challenge for the further industrialization of additive manufacturing. To solve this challenge, methods for measuring the process states and properties of parts during additive manufacturing are essential. The subject of this review is in-situ process monitoring for material extrusion additive manufacturing. The objectives are, first, to quantify the research activity on this topic, second, to analyze the utilized technologies, and finally, to identify research gaps. Various databases were systematically searched for relevant publications and a total of 221 publications were analyzed in detail. The study demonstrated that the research activity in this field has been gaining importance. Numerous sensor technologies and analysis algorithms have been identified. Nonetheless, research gaps exist in topics such as optimized monitoring systems for industrial material extrusion facilities, inspection capabilities for additional quality characteristics, and standardization aspects. This literature review is the first to address process monitoring for material extrusion using a systematic and comprehensive approach.
\end{abstract}

Keywords Material extrusion · Fused deposition modeling · Process monitoring · Quality assurance $\cdot$ Sensor technology · Research gaps

\section{Introduction}

Additive manufacturing is already an accepted technology for special applications and prototype production. However, it has considerable potential for further expansion in the future [1]. Examples of future applications are small-batch productions in the automotive [2] and aerospace [3] sectors as well as the production of customized medical devices [4]. Additive manufacturing can further be used in the jewelry [5] and construction industries [6]. Niche applications include mouthpieces for musical instruments [7] or textiles for clothing [8].

Solving the challenge of qualitative uncertainties in terms of materials, processes, and products, as well as process knowledge deficits, is vital to further incorporate additive

Alexander Oleff

oleff@iph-hannover.de

1 Institut für Integrierte Produktion Hannover gGmbH, Hollerithallee 6, 30419 Hannover, Germany

2 Leibniz University Hannover, Institute of Transport and Automation Technology, An der Universität 2, 30823 Garbsen, Germany manufacturing in the industry $[9,10]$. Therefore, providing tools for comprehensive quality management is essential [11, 12]. Means of measuring process states and part properties during additive manufacturing are particularly relevant to achieving this aim [9, 13-15].

Process monitoring enables the assessment of whether a product satisfies certain requirements. In-situ inspection techniques fundamentally increase customer confidence in a product and reduce costs due to rejection, because process anomalies are detected immediately after they occur. Furthermore, information from process monitoring is the basis for implementing a closed-loop quality control [16]. A significant challenge for testing technologies in the field of additive manufacturing is the complex geometries of parts that contain infill structures and process-specific defects [17, 18]. This review aims to identify and analyze the existing literature on in-situ process monitoring for material extrusion (MEX), as it is one of the most widely used additive process categories $[1,19]$.

Former reviews, specifically on the additive manufacturing of metal parts, have already been published [17, 20,21]. Their focus lies on monitoring techniques for powder bed [22] fusion and directed energy deposition [16, 23-27]. The 
results of these studies are not directly transferable to MEX because additive process categories are significantly different due to dissimilar processing principles being applied [9]. However, a number of reviews which comprise a wider range of additive process categories have been published: Vora and Sanyal [28] investigated the usability of different conventional inspection techniques for process monitoring in additive manufacturing. Their focus was the analysis of general functional principles. Process monitoring in MEX was merely minimally addressed. Charalampous et al. [29] discussed the research on sensor-based quality monitoring before, during, and after the additive manufacturing process. They presented nine different projects on MEX in-situ process monitoring. Controlling the additive processes using sensor technologies was the focus of a study [30] that listed commercially available solutions in addition to research work. It included eleven references regarding MEX. Lu and Wong [14] presented fundamental challenges and developed principles for monitoring with thermography, and acoustic emissions. However, MEX was only considered to a very limited extent. A review on ultrasonic testing by Honarvar and Varvani-Farahani [31] discussed two MEX projects. Furthermore, applications of machine learning have already been discussed in various publications [32-34]. One of their topics was process monitoring, but the presentation of MEX projects was marginal.

In summary, the studies on hand provide only a rather limited insight into the subject matter of MEX in-situ process monitoring. A comprehensive and systematic analysis of the state of knowledge has yet to be conducted. Therefore, the aim of this study is to compile and structure the current state of research using an approach that is as objective and comprehensive as possible. The following three central questions will be answered:

- How much activity is involved in the field of process monitoring?

- What methods and technologies are used for the process monitoring of which quality characteristics?

- What are the research gaps?

After an overview of the fundamentals of MEX in Sect. 2, the methodology for the literature search and analysis is introduced in Sect. 3. Subsequently, in Sects. 4, 5, and 6 the results are presented and discussed, structured according to the abovementioned questions. Finally, Sect. 7 summarizes the main conclusions of the study.

\section{Material extrusion}

In MEX, a feedstock is extruded and deposited in beads by the relative movement between a nozzle and a substrate. During extrusion, the material is in a semi-solid state and solidifies when it reaches its final position and shape [19, 35]. Various sub-categories are grouped under the MEX process category. They differ in the type of extruder (plunger, gear, or screw), form of feedstock (filaments, rods, or pellets) [36], and kinematic design (Cartesian, polar, delta, or robot arm) [37].

The advantages of MEX are the simplicity of the process, relatively low costs [9] and a large variety of feedstock materials [38]. In addition to standard plastics, fiber-reinforced polymers can also be processed [39]. Furthermore, it is possible to produce parts from concrete [6], metals, ceramics, and multiple materials [36]. Because of the high material deposition rates that can be achieved [40], special MEX systems can be used for large-format additive manufacturing (build volumes of over $1 \mathrm{~m}^{3}$ ) [41]. MEX can compete with conventional manufacturing processes in terms of cost per unit for small and medium batch sizes [42]. An example of an application in this batch size range is polymer components for the aircraft industry [43].

Numerous influencing variables (e.g., process parameters and material properties) affect the mechanical and geometric properties as well as the surface characteristics of the parts produced by MEX [39, 44, 45]. Depending on the application, the requirements for the parts differ. Therefore, only certain quality characteristics related to the respective requirements are the target of process monitoring. Examples of quality characteristics are the geometric dimensions and density of parts [46]. Owing to the complex interactions among different influencing variables, various process faults that can negatively affect the quality of parts may occur. A selection of typical part defects is listed in Table 1.

\section{Materials and methods}

This study can be considered as a state-of-the-art review based on the classification of different review types by Grant and Booth [56]. The focus is on the presentation of the current status as well as the identification of research gaps. During the literature search step, as many thematically congruent publications as possible are identified using a systematic and reproducible search methodology. There is no evaluation and selection of publications based on the relevance of the study results and the quality of the study design. An aggregative approach is used to synthesize the identified sources by collecting and interpreting empirical 
Table 1 Typical part defects in material extrusion

\begin{tabular}{|c|c|c|c|}
\hline Defect & Cause & Outcome & References \\
\hline Bubbles and bulges & $\begin{array}{l}\text { Moisture bound in the material evaporates } \\
\text { explosively during processing }\end{array}$ & $\begin{array}{l}\text { Compromised mechanical properties, } \\
\text { impaired surface quality }\end{array}$ & {$[47,48]$} \\
\hline Incorrect bead deposition position & $\begin{array}{l}\text { Faults in the kinematic structure, printing of } \\
\text { unsupported overhangs }\end{array}$ & Geometric deviations & [49-51] \\
\hline Overfill & $\begin{array}{l}\text { Incorrect process parameters, errors in } \\
\text { motion control }\end{array}$ & Increased bead width, bump formation & {$[50,52,53]$} \\
\hline Scars & $\begin{array}{l}\text { Nozzle grinds over the previously printed } \\
\text { layer }\end{array}$ & Impaired surface quality & {$[50]$} \\
\hline Stringing & $\begin{array}{l}\text { Printing temperature too high, incorrect fila- } \\
\text { ment retraction settings }\end{array}$ & $\begin{array}{l}\text { Material oozes out of the nozzle of the mov- } \\
\text { ing extruder, even though no extrusion is } \\
\text { intended }\end{array}$ & {$[50,54]$} \\
\hline Underfill & $\begin{array}{l}\text { Faults in the kinematic structure, clogged } \\
\text { nozzle, incorrect process parameters }\end{array}$ & $\begin{array}{l}\text { Voids, reduced bead width, stopped mate- } \\
\text { rial extrusion, compromised mechanical } \\
\text { properties }\end{array}$ & {$[50,52,53,55]$} \\
\hline Warpage and shrinkage & Temperature gradients in the part & Delamination, cracking, part deformation & {$[50,51]$} \\
\hline
\end{tabular}

Fig. 1 Process of systematic search and criteria-based filtering with the specification of the number of considered records (n) in each step

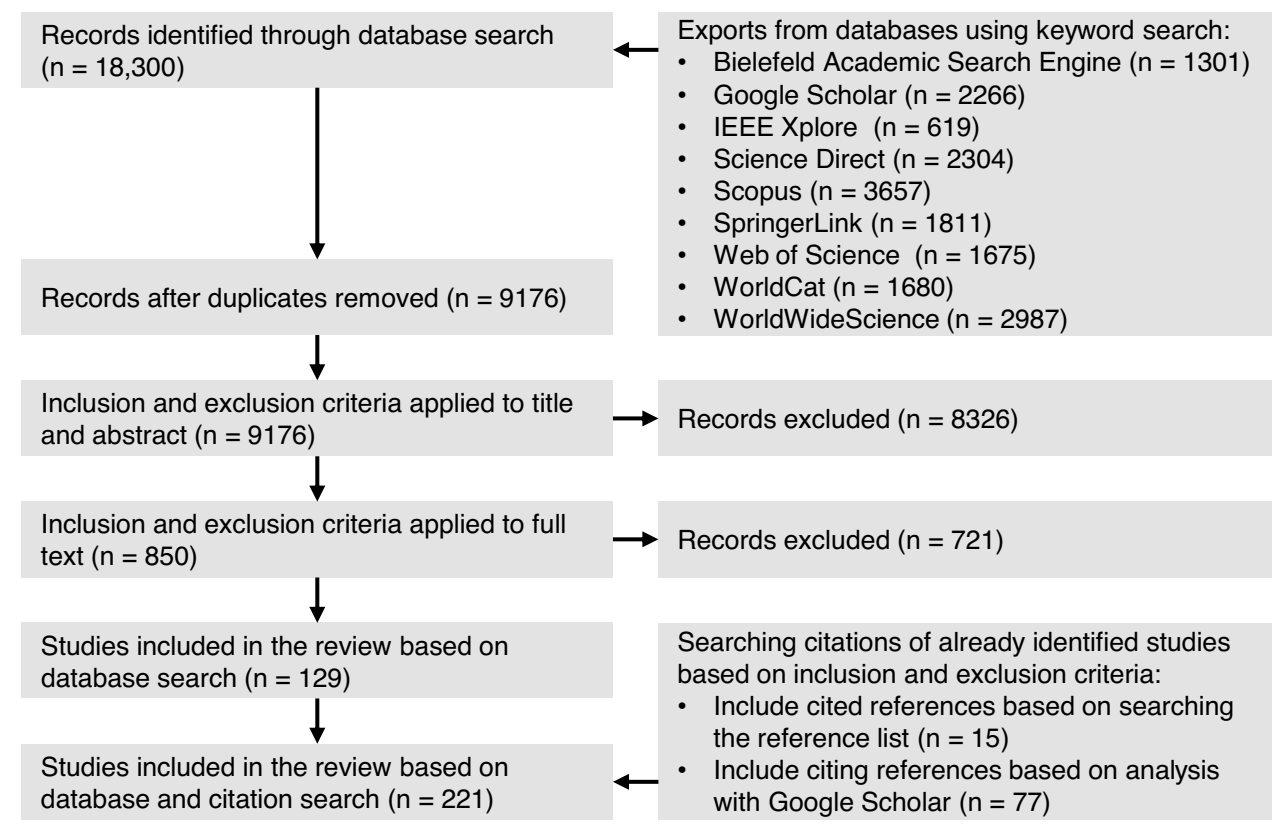

data. In addition, a primary purpose is to provide an understanding of relevant research directions and topics [57].

The process of literature search shown in Fig. 1 included, as a first step, a literature search of nine different popular databases in February 2020. Each database was searched multiple times. The searches corresponded to the keyword ("fused deposition modeling" OR "fused deposition modelling" OR "fused filament fabrication" OR "material extrusion" OR "fused layer modeling" OR "filament freeform fabrication") AND ("process" OR "quality" OR "defect" OR "error" OR "fault" OR “condition") AND ("assurance" OR "control" OR "detection" OR "inspection" OR "measurement" OR "metrology" OR “monitoring” OR “sensor”). Single search operations contained only one term for naming the additive manufacturing process (first operand for the Boolean AND operators). Therefore, six individual searches were performed to query the keyword completely. In each database, the entire record was searched, but the number of exported hits was limited to 500 per single search operation. If the database supported a limitation of the search to titles, abstracts, and keywords of the publications, an additional search in these categories was performed without limitation on the number of exported hits.

After removing the duplicates with the aid of the literature management software Citavi (Swiss Academic Software $\mathrm{GmbH}$ ), the dataset contained 9176 entries. To analyze relevant sources only, inclusion and exclusion criteria were 
defined and applied to the dataset. The inclusion criteria were:

- one of the sub-categories of MEX is treated;

- central aim is in-situ process monitoring for quality assurance (assessing the status of 3D printer components or parts in production);

- contribution is original research (peer-reviewed), dissertation or active patent.

The exclusion criteria were:

- process monitoring is included but not for the purpose of quality assurance (e.g., sensor system to validate a simulation of the MEX process);

- not in English or German;
- older than 2013.

A total of 221 elements comprise the dataset for the review. The approach to analyze the identified publications, as well as the paper's corresponding sections, is presented in Fig. 2.

\section{How much activity is involved in the field of process monitoring?}

The analysis of the publication dates of the contributions in Fig. 3 shows that publication activity is growing steadily, and the research activity in the field of process monitoring has been gaining importance. Growth rates since 2013 have at least been in the same range as those found by Vyavahare
Fig. 2 Approach to analyze the identified publications
Fig. 3 Publication activity by calendar year

\begin{tabular}{|c|c|c|c|}
\hline Quantify & Subject of analysis & $\begin{array}{l}\text { Methodology of } \\
\text { analysis }\end{array}$ & Section \\
\hline $\begin{array}{l}\text { How much activity } \\
\text { is involved in the } \\
\text { field of process } \\
\text { monitoring? }\end{array}$ & $\begin{array}{l}\text { - Number of publications depending on } \\
\text { - calendar year } \\
\text { - monitoring system functionality level } \\
\text { - monitoring system stage of development } \\
\text { - material extrusion sub-category } \\
\text { - Number of projects }\end{array}$ & - Statistical analysis & $\cdot 4$ \\
\hline \multicolumn{4}{|l|}{ Summarize } \\
\hline \multirow{2}{*}{$\begin{array}{l}\text { What methods } \\
\text { and technologies } \\
\text { are used for the } \\
\text { process } \\
\text { monitoring of } \\
\text { which quality } \\
\text { characteristics? }\end{array}$} & $\begin{array}{l}\text { - Percentage of } \\
\text { - used sensor technology groups } \\
\text { - monitored elements }\end{array}$ & - Statistical analysis & $\cdot 5.1$ \\
\hline & $\begin{array}{l}\text { - Data of every project regarding } \\
\text { - sensor technology } \\
\text { - data handling } \\
\text { - monitored quality characteristics } \\
\text { - functionality level } \\
\text { - stage of development }\end{array}$ & $\begin{array}{l}\text { - Tabular survey of } \\
\text { every project } \\
\text { - Narrative survey of } \\
\text { key projects }\end{array}$ & $\begin{array}{c}\cdot 5.2- \\
5.10\end{array}$ \\
\hline \multicolumn{4}{|l|}{ Evaluate } \\
\hline \multirow{4}{*}{$\begin{array}{l}\text { What are the } \\
\text { research gaps? }\end{array}$} & - Sensor technology and data processing & $\begin{array}{l}\text { - Comparison with } \\
\text { ideal state }\end{array}$ & $\cdot 6.1$ \\
\hline & - Monitored quality characteristics & - Statistical analysis & $\cdot 6.2$ \\
\hline & - Capability of monitoring systems & - Statistical analysis & $\cdot 6.3$ \\
\hline & - State of standardization & - Discussion & $\cdot 6.4$ \\
\hline
\end{tabular}

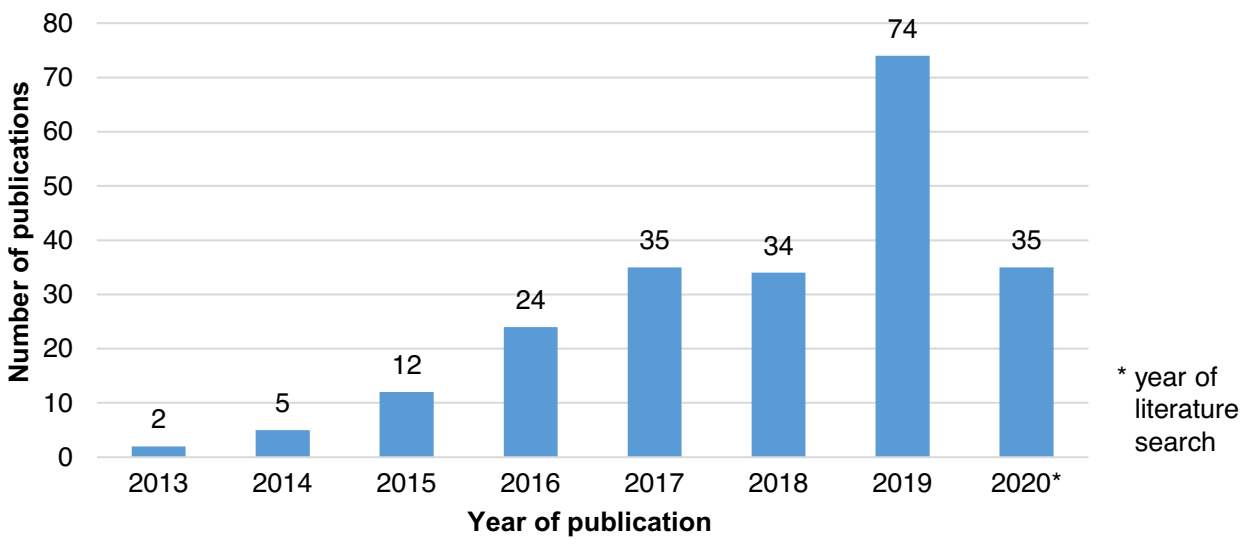


et al. [15] for the MEX research area in general. It should be noted that the value for the year 2020 cannot be interpreted directly because the process of searching the literature had been completed midyear.

The publication activity varies in the different subcategories of MEX. The majority of the identified studies can be assigned to the field of monitoring techniques for fused deposition modeling [35]. The other sub-categories addressed are large-format MEX [58-63], bioprinting [64], and direct ink writing [65-68]. In addition to the processing of conventional filaments, some studies have examined manufacturing processes for continuous fibers $[69,70]$, pastes [71], and pellets [60, 62, 63, 72, 73]. Publications addressing MEX machines with delta [74-88] and robot arm [58, $72,73,89-92]$ kinematics are exceptions to the considered Cartesian systems.

Some monitoring systems have been published several times and sometimes, several systems have been described in one publication. The grouping of sources according to project affiliation indicated that the dataset involved 145 different MEX monitoring systems. The criteria for grouping the sources according to project affiliation were research group membership and sensor technology.

For further characterization of the dataset, Fig. 4 illustrates which levels of functionalities of a process monitoring system have been addressed by the publications and in which development stage they are. The sensor system (F1) is a pure hardware setup. In the level that builds on it, data are processed and extracted (F2), e.g., for visualization. The third functionality level describes the automated data evaluation (F3) for the detection of anomalies. A closed-loop control (F4) represents the maximum possible functionality level of a monitoring system. Note that these categories progress in a typical order $(\mathrm{F} 1 \rightarrow \mathrm{F} 2 \rightarrow \mathrm{F} 3 \rightarrow \mathrm{F} 4)$, where the latter categories necessitate accomplishment of the prior categories. Publications are placed in the highest category that their content represents. The stage of development is described with the following classifications: patent $(\mathrm{P})$, preliminary studies (D1), and realized solution (D2).

Figure 4 shows that the current focus of research is in F3 since the maximum number of D1 and D2 occurs on this level of functionality. However, the conspicuously high number of patents in F4 indicates that an economic benefit is seen particularly for this level of functionality. In the long term, therefore, further research activity can be expected in this area.

\section{What methods and technologies are used for the process monitoring of which quality characteristics?}

\subsection{Sensor technology groups and inspected elements}

Various sensor technologies are used for process monitoring. Figure 5 displays the percentage shares of sensor technology groups in the total number of sensors used. The grouping is based on the measured physical quantities. The respective share of each sensor technology that is used simultaneously with another is represented by the "sensor fusion" section of the bar. Furthermore, all sensor technologies that have a share of less than $2 \%$ in the "one sensor technology" section and cannot be assigned to the other groups are collected under "other."

Figure 6 depicts a statistical analysis of which elements of the additive manufacturing process are directly monitored by which sensor technology groups. On one hand, it is possible to monitor the components of the MEX machine that have an influence on the part quality. According to the main functional components of the MEX machine [19, 35, 45], the following are distinguished:
Fig. 4 Functionality of the examined monitoring systems depending on the stage of development

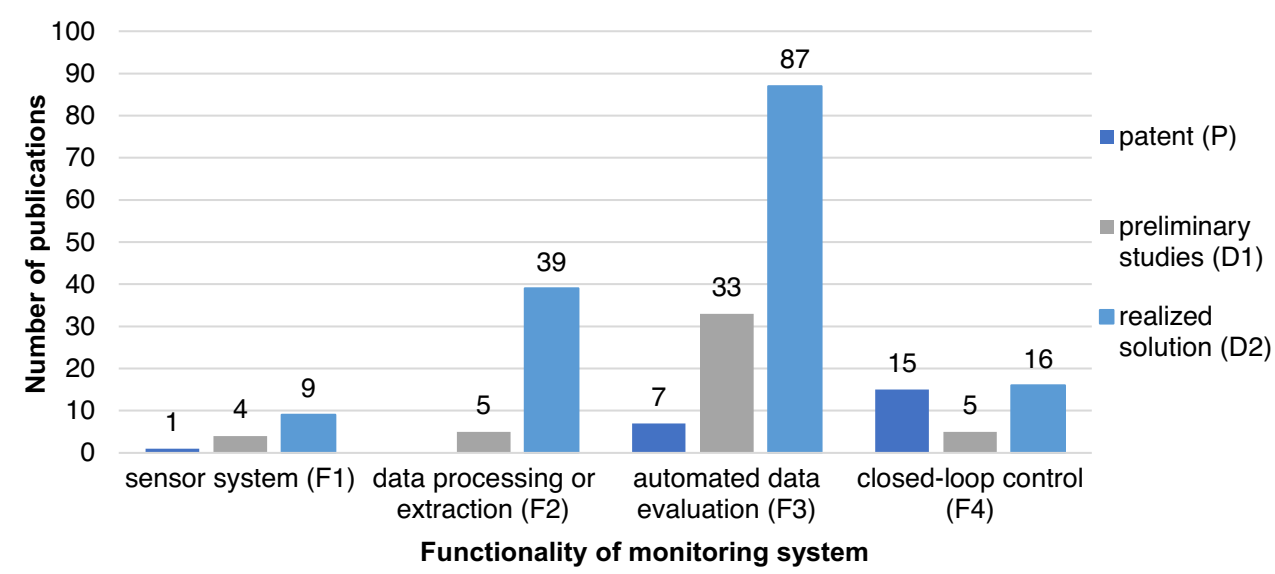


Fig. 5 Percentage of sensor technologies in the total number of sensors
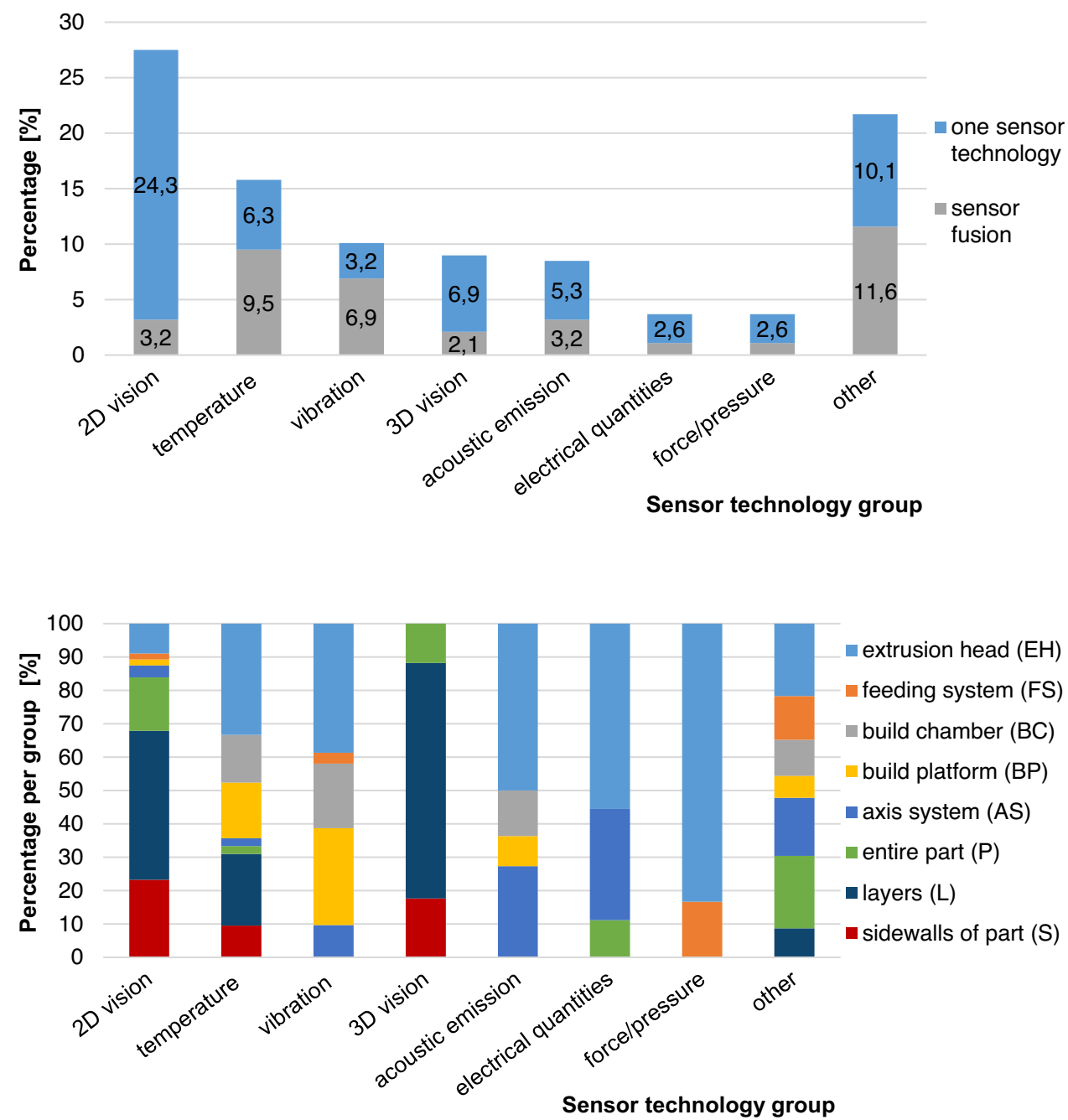

Fig. 6 Sensor technology groups and inspected elements
- extrusion head $(\mathrm{EH})$, including the extrusion nozzle and feedstock delivery mechanism;

- feeding system (FS), for feedstock transport to the extrusion head;

- build chamber (BC), including the housing and frame;

- build platform (BP); and

- axis system (AS), including the motors.

On the other hand, the part can be directly monitored. The following are distinguished depending on the area of monitoring:

- entire part $(\mathrm{P})$;

- layers (L), equivalent to the build surfaces in the majority of cases; and

- $\quad$ sidewalls of part $(\mathrm{S})$.

Figure 6 shows that the measurement of vibration, acoustic and electrical signals, as well as force and pressure, is primarily used to monitor the components of the
MEX machine. The part is inspected primarily using vision technologies. The focus is on monitoring the extrusion head and individual layers.

The following subsections describe the identified publications sorted by sensor technology groups and project affiliations. The general functional principles are introduced, and selected monitoring systems are explained precisely. For detailed descriptions of the treated sensor types and their general advantages and disadvantages, the reader can refer to Vora and Sanyal [28].

\subsection{D vision}

In Table 2, the projects identified within the field of 2D vision are listed, along with their associated references. The projects were sorted based on the following priority: (1) used sensors (column "Sensors"), (2) inspected elements (column "Ele"), (3) project level of functionality (column "Fun"), and (4) stage of development (column "Dev"). The column "Data handling" provides a brief description of the methods 
Table 2 Summary of publications on 2D vision

\begin{tabular}{|c|c|c|c|c|c|c|}
\hline References & Sensors & Ele & Data handling & Quality characteristics & Fun & Dev \\
\hline [93] & Camera & EH & Convolutional neural network & Offset nozzle height & F3 & D2 \\
\hline [94] & Camera & AS & Comparison with G-code & Area of layer & F3 & D2 \\
\hline [95] & Camera & AS & Comparison with ideal process & Voids & F3 & D2 \\
\hline [96] & Camera & $\mathrm{P}$ & $\begin{array}{l}\text { Cascade classifiers, comparison with } \\
\text { simulated reference image }\end{array}$ & Geometric deviations & F3 & D1 \\
\hline [97] & Camera & $\mathrm{P}$ & $\begin{array}{l}\text { Principal component analysis and } \\
\text { support vector machine, convolu- } \\
\text { tional neural network }\end{array}$ & Defective part & F3 & D2 \\
\hline [98] & Camera & $\mathrm{P}$ & Deep learning & Defective process & F3 & D2 \\
\hline [99] & Camera & $\mathrm{L}$ & Image visualization & Layer surface & $\mathrm{F} 2$ & D1 \\
\hline [100] & Camera & $\mathrm{L}$ & Contour detection & Geometric deviations & $\mathrm{F} 2$ & D2 \\
\hline [101] & Camera & $\mathrm{L}$ & Visualizing in mixed reality & Not applicable (n.a.) & $\mathrm{F} 2$ & D2 \\
\hline$[102,103]$ & Camera & $\mathrm{L}$ & Comparison with reference & Infill structure, part position & F3 & D1 \\
\hline [89] & Camera & $\mathrm{L}$ & Comparison with reference & Geometric deviations & F3 & D1 \\
\hline [104-106] & Camera & $\mathrm{L}$ & $\begin{array}{l}\text { Naive Bayes classifier, decision } \\
\text { trees, random forest, k-nearest } \\
\text { neighbors, anomaly detection, } \\
\text { cyber-physical alert correlation }\end{array}$ & Infill structure voids & F3 & D2 \\
\hline [107] & Camera & $\mathrm{L}$ & Comparison with STL file & Geometric deviations & $\mathrm{F} 3$ & D2 \\
\hline [108] & Camera & $\mathrm{L}$ & Random forest & Infill structure voids & F3 & D2 \\
\hline [58] & Camera & $\mathrm{L}$ & Data fusion, measurements & $\begin{array}{l}\text { Bead thickness/intersections/ align- } \\
\text { ment, geometry }\end{array}$ & F3 & D2 \\
\hline [65] & Camera & $\mathrm{L}$ & Comparison with G-code & Voids, bead shape & F3 & D2 \\
\hline$[109,110]$ & Camera & $\mathrm{L}$ & Statistical process control & Layer contour, overfill, underfill & F3 & D2 \\
\hline [111] & Camera & $\mathrm{L}$ & Comparison with tolerance range & Geometric deviations & $\mathrm{F} 4$ & $\mathrm{P}$ \\
\hline [112] & Camera & $\mathrm{L}$ & Convolutional neural network & Overfill, underfill & $\mathrm{F} 4$ & D2 \\
\hline [113] & Camera & $\mathrm{S}$ & Differential imaging, blob detection & $\begin{array}{l}\text { Detachment, geometric deviations, } \\
\text { stopped material flow }\end{array}$ & F3 & D2 \\
\hline$[114,115]$ & Camera & $\mathrm{S}$ & Image mining & Part quality & F3 & D2 \\
\hline$[88,116]$ & Camera & $\mathrm{S}$ & Neural network & $\begin{array}{l}\text { Blobs, voids, thick beads, crack, } \\
\text { misalignment }\end{array}$ & F3 & D2 \\
\hline [92] & Camera & $\mathrm{S}$ & $\begin{array}{l}\text { Comparison with ideal, deep rein- } \\
\text { forcement learning }\end{array}$ & Geometric deviations & $\mathrm{F} 4$ & D2 \\
\hline [117] & $1 /$ multiple cameras & $\mathrm{S}$ & Comparison with ideal & Geometric deviations & F4 & $\mathrm{P}$ \\
\hline [118] & $1 /$ multiple cameras & $\mathrm{L}, \mathrm{S}$ & Comparison with CAD model & Parts geometry/position & F3 & $\mathrm{P}$ \\
\hline [119-126] & 5 cameras & $\mathrm{S}$ & Comparison with reference & Extrusion stop, material color & F3 & D2 \\
\hline [127] & Camera, illumination & $\mathrm{P}$ & Comparison with CAD model & Geometric deviations & F3 & D2 \\
\hline [128] & Camera, illumination & $\mathrm{P}$ & Comparison with reference & Warping, detachment, extrusion stop & F3 & D2 \\
\hline [129] & Camera, illumination & $\mathrm{L}$ & Comparison with STL file & Geometric deviations & F3 & D1 \\
\hline$[130]$ & Camera, illumination & $\mathrm{L}$ & Texture analysis & $\begin{array}{l}\text { Layer surface irregularities, geomet- } \\
\text { ric deviations }\end{array}$ & F3 & D1 \\
\hline [131-133] & Camera, illumination & $\mathrm{L}$ & Statistical process control & Layer contour & F3 & D2 \\
\hline [134] & Camera, illumination & $\mathrm{L}$ & $\begin{array}{l}\text { Comparison with ideal part, support } \\
\text { vector machine }\end{array}$ & Defective parts & F3 & D2 \\
\hline [59] & Camera, illumination & $\mathrm{S}$ & Fourier analysis & Layer height & F3 & D1 \\
\hline [75] & Camera, illumination & $\mathrm{S}$ & Comparison with STL file & Geometric deviations & F3 & D2 \\
\hline [135] & Camera, illumination & $\mathrm{S}$ & Comparison with reference & Layer shifting & F3 & D2 \\
\hline$[90,91]$ & Camera, illumination & $\mathrm{S}$ & $\begin{array}{l}\text { Measurements, comparison with } \\
\text { theoretical model }\end{array}$ & Voids, shape contour & F3 & D2 \\
\hline [136] & $1 /$ multiple cameras, illumination & $\mathrm{P}$ & Comparison with G-code & $\begin{array}{l}\text { Detachment, extrusion stop, geomet- } \\
\text { ric deviations }\end{array}$ & F3 & $\mathrm{P}$ \\
\hline$[66,67]$ & $2 / 3$ cameras, illumination & $\mathrm{EH}, \mathrm{L}$ & Various measurements & $\begin{array}{l}\text { Bead structures, deposition area } \\
\text { characteristics }\end{array}$ & F3 & D2 \\
\hline
\end{tabular}


Table 2 (continued)

\begin{tabular}{|c|c|c|c|c|c|c|}
\hline References & Sensors & Ele & Data handling & Quality characteristics & Fun & Dev \\
\hline [137] & Multiple cameras, illumination & $\mathrm{P}$ & $\begin{array}{l}\text { Comparison with CAD model, } \\
\text { hidden Markov models, Bayesian } \\
\text { inference, neural network }\end{array}$ & Outer surface of part & $\mathrm{F} 4$ & $\mathrm{P}$ \\
\hline [138] & Line scan camera, illumination & $\mathrm{L}$ & n.a & Defective process & F3 & $\mathrm{P}$ \\
\hline [139-155] & Camera, flatbed scanner & $S$ & $\begin{array}{l}\text { Texture analysis for feature extrac- } \\
\text { tion }\end{array}$ & Surface quality & F3 & D1 \\
\hline [156] & Flatbed scanner & $\mathrm{L}$ & Distortion adjustment & Layer contour & F1 & D1 \\
\hline$[157,158]$ & Digital microscope & $\mathrm{EH}$ & $\begin{array}{l}\text { Measurements, filament feed speed } \\
\text { control }\end{array}$ & $\begin{array}{l}\text { Feeding gear slippage, material flow } \\
\text { rate }\end{array}$ & $\mathrm{F} 4$ & D2 \\
\hline [159] & Digital microscope & $\mathrm{L}$ & Image visualization & Voids, bead shape & F1 & D2 \\
\hline$[160-162]$ & 2 digital microscopes, illumination & $\mathrm{L}$ & $\begin{array}{l}\text { Texture analysis, k-nearest neigh- } \\
\text { bors, naive Bayes classifier, linear } \\
\text { discriminant analysis, support vec- } \\
\text { tor machine, PID controller }\end{array}$ & Overfill, underfill & F4 & D2 \\
\hline [163] & Optical sensor & FS & n.a & Material flow rate & F4 & $\mathrm{P}$ \\
\hline
\end{tabular}

used for sensor data processing. "Quality characteristics" are the features checked by the monitoring system. If the publications on a project do not contain certain information, this is indicated in the corresponding cell with the phrase "not applicable" ("n.a.").

The generic term $2 \mathrm{D}$ vision is used in this paper to describe all sensor technologies that acquire two-dimensional images of an object in the visible wavelength range. Seven of the 23 patents identified in this work exclusively addressed 2D vision [111, 117, 136-138, 163]. Therefore, the potential of the sensor technology for MEX process monitoring is considered high by the industry.

The 2D vision technology is often used for the sequential inspection of layers. One technical variant includes mounting the sensor on the extrusion head [58, 65-67, 89, 104-106, 111, 112, 159-162]. For example, Liu et al. [160, 161] investigated overfill and underfill defects using two digital microscopes, which were attached to the extrusion head to continuously analyze the layer surface in a small area next to the nozzle (Fig. 7). For the extraction of features, a texture analysis method in which the layer surface was described with a gray-level co-occurrence matrix was used. Subsequently, the layer surface was divided into five classes using the k-nearest neighbors algorithm. The material flow rate and speed of the cooling fan on the extrusion head were adjusted using a proportional-integral-derivative (PID) controller according to the classification to increase the layer quality.

In addition to projects that include mounting vision sensors on the extrusion head, another relevant approach is the stationary mounting of the camera with a view on the build platform. In this scenario, the entire layer is captured in one image acquisition [100, 101, 104-110, 129-134]. In one of the projects [131-133], statistical process control is used to evaluate the quality of the layer contours. Significant changes in the process caused by the exceedance of tolerance limits were displayed on quality control charts. In contrast, Delli et al. [134] compared images of a defect-free part with the actual manufactured part and used both a simple threshold method and a support vector machine to classify the part into one of two categories: good or bad.
Fig. 7 Investigation of layer surface quality using two digital microscopes. Adapted from [160], copyright 2019, with permission from The Society of Manufacturing Engineers

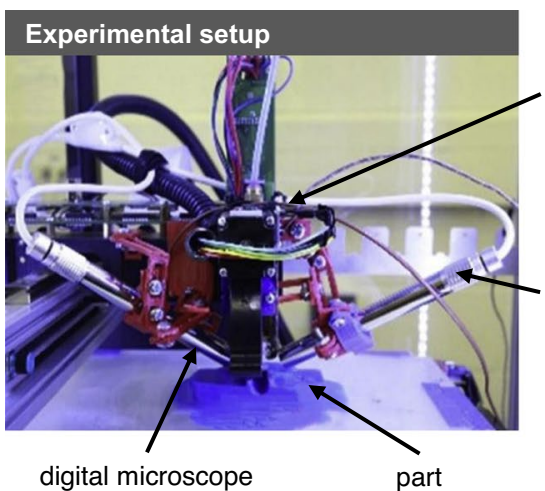

extrusion head

underfill

digital

microscope

nozzle tip

normal extrusion

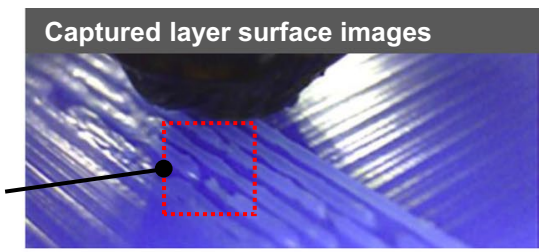

closed-loop control

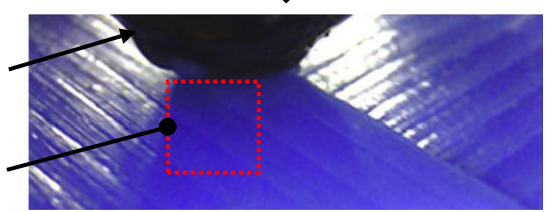


Aside from process monitoring of individual layers, 2D vision sensors may also be used for the exclusive inspection of the sidewalls of parts. In this technical variant, the camera axis is often perpendicular to the normal vector of the build platform. Baumann et al. [113] used this approach to detect deformations on printed objects, detachments from the build platform, and lack of material flow. Because the 3D printer is a desktop device with an open housing, the camera can be placed in front of the 3D printer to capture images of one side of the part.

The use of a camera to inspect sidewalls in large-format additive manufacturing was investigated by MacDonald et al. [59]. Fourier analysis was used to determine the variation in layer heights from the image data. Due to the large size of the beads, they can be easily distinguished from one another with an algorithm. Especially in large-format MEX with pellet feedstock, the extrusion process is highly sensitive to parameter variations. The authors demonstrated that the resulting slumping of beads or small irregularities protruding from the sidewalls could be detected with the monitoring system.

In a series of publications, Straub [119-126] presented a sensor system consisting of five cameras arranged around the build platform. For data acquisition, the printing process is stopped, and the build platform is moved to a predefined position. Besides the use of multiple cameras, mobile solutions to move the camera around the object to be printed have been proposed in further studies [88, 90, 117]; thus, the sidewalls of the part can be fully captured. Figure 8 shows this as an example with a camera attached to the extrusion head of a robot MEX system using a special mount.

In addition to the inspection of manufactured parts, some systems also use 2D vision to monitor the mechanical components of a 3D printer. Greeff et al. [157, 158] utilized a digital microscope to inspect the filament delivery mechanism in an extrusion head. The speed and width of the filament were measured to calculate the volume flow. Moreover, the speed of the feeding gear was determined and compared with that of the filament to calculate slippage effects.

\subsection{Temperature monitoring}

Since materials are melted because of heat during MEX, the acquisition of temperature data is a practical method for evaluating the condition of the manufacturing process. Table 3 summarizes the corresponding publications. Temperature sensors for measuring and controlling the temperature of the build platform, extruder, and ambient air in the build chamber are conventionally installed in many MEX systems [178]. However, aside from sensors that are in contact with the measured surface, a large portion of the identified publications involve temperature determination via thermography. Thermography is an imaging technique used to display the surface temperature of objects. The intensity of the infrared radiation serves as a measure of the temperature.

Thermal cameras are often used to determine the temperature of the layers. Borish et al. [60] developed a method for calculating the average temperature of a layer in large-format MEX. They paused the printing process until the temperature decreases below a certain value. When this condition is attained, the next layer can be processed. The thermal camera is attached to a movable arm that is pneumatically driven. The study shows that temperature measurements are particularly relevant for large-format additive manufacturing since in rapid printing processes cooling times are sometimes insufficient and parts collapse under their own weight.

Monitoring the sidewall of a part with a thermal camera, Ferraris et al. [171] determined a correlation between the characteristic temperature curves and the size of the bonding surfaces between adjacent beads. Using a similar hardware setup, the tensile strength of samples was predicted in a work by Bartolai et al. [173, 174].

\subsection{Vibration monitoring}

Vibration can be measured at many of the mechanical components of the 3D printer (Table 4). A key issue is the monitoring of extrusion head vibrations. Tlegenov et al. [181, 182] attached an accelerometer to an extruder to determine
Fig. 8 Camera attached to the extrusion head of a robotic MEX system for continuous multi-view inspection of sidewalls. Adapted from [90], (C) Emerald Publishing Limited all rights reserved, with permission from Emerald Publishing Limited

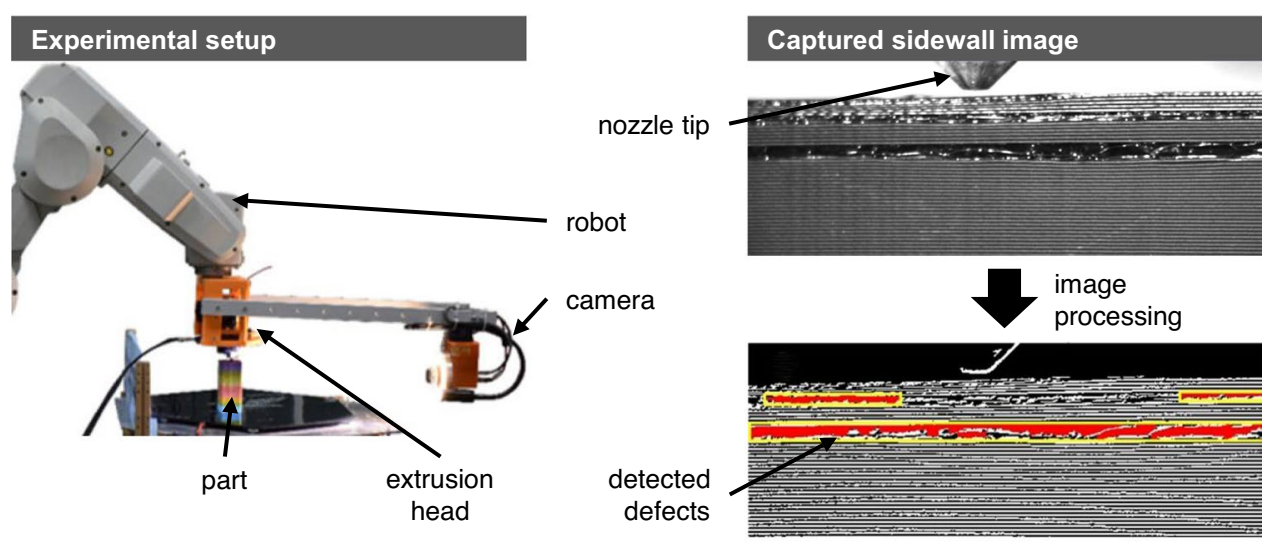


Table 3 Summary of publications on temperature monitoring

\begin{tabular}{|c|c|c|c|c|c|c|}
\hline References & Sensors & Ele & Data handling & Quality characteristics & Fun & Dev \\
\hline [164] & Thermal camera & EH & Temperature control methods & Polymer melt temperature & F4 & D2 \\
\hline [165] & Thermal camera & $\mathrm{L}$ & Spatial and time-domain data processing & Layer temperature & $\mathrm{F} 2$ & D2 \\
\hline [166-168] & Thermal camera & $\mathrm{L}$ & Sensing with limited sensor data & Layer temperature & $\mathrm{F} 2$ & D2 \\
\hline$[169,170]$ & Thermal camera & $\mathrm{L}$ & $\begin{array}{l}\text { Rules of knowledge, support vector } \\
\text { machine }\end{array}$ & $\begin{array}{l}\text { Nozzle clogging, warping, underfill, } \\
\text { geometric deviations }\end{array}$ & F3 & D2 \\
\hline [60] & Thermal camera & $\mathrm{L}$ & $\begin{array}{l}\text { Process temperature data, control layer } \\
\text { start time }\end{array}$ & Short layer build times & F4 & D2 \\
\hline [171] & Thermal camera & $\mathrm{S}$ & Spatial and time domain data processing & $\begin{array}{l}\text { Surface temperature, bond shape between } \\
\text { beads }\end{array}$ & $\mathrm{F} 2$ & D2 \\
\hline [61] & Thermal camera & $S$ & Spatial domain data processing & Temperature profiles & $\mathrm{F} 2$ & D2 \\
\hline [172] & Thermal camera & $\mathrm{S}$ & Correct temperature measurements & Surface temperature & $\mathrm{F} 2$ & D2 \\
\hline$[173,174]$ & Thermal camera & $\mathrm{S}$ & Analytical prediction model & $\begin{array}{l}\text { Temperature of weld interface, part tensile } \\
\text { strength }\end{array}$ & F3 & D2 \\
\hline [175] & Infrared & EH & n.a & Irregular material flow & F4 & $\mathrm{P}$ \\
\hline$[176,177]$ & 2 thermistors & EH & Feed-forward control & Temperature of nozzle/heater block & F4 & D2 \\
\hline [178] & 3 thermistors & $\mathrm{EH}, \mathrm{BC}, \mathrm{BP}$ & PID controller & Local temperatures & F4 & D1 \\
\hline [179] & 3 thermocouples & $\mathrm{L}$ & Time domain data processing & Local layer temperature & $\mathrm{F} 2$ & D2 \\
\hline [180] & $\begin{array}{l}\text { Infrared, ther- } \\
\text { mocouple, } \\
\text { thermistor }\end{array}$ & $\mathrm{EH}, \mathrm{BP}, \mathrm{L}$ & $\begin{array}{l}\text { Neural network, support vector machine, } \\
\text { linear regression, PID controller }\end{array}$ & Distortion & F4 & D2 \\
\hline
\end{tabular}

Table 4 Summary of publications on vibration monitoring

\begin{tabular}{|c|c|c|c|c|c|c|}
\hline References & Sensors & Ele & Data handling & Quality characteristics & Fun & Dev \\
\hline$[181,182]$ & Accelerometer & $\mathrm{EH}$ & $\begin{array}{l}\text { Analytical model, frequency and time domain } \\
\text { analysis }\end{array}$ & Nozzle clogging & $\mathrm{F} 2$ & D2 \\
\hline [183] & Accelerometer & AS & $\begin{array}{l}\text { Logistic regression, support vector machine, } \\
\text { random forest }\end{array}$ & Warping, extrusion stop & F3 & D2 \\
\hline [184] & Accelerometer & n.a & $\begin{array}{l}\text { Frequency and time domain analysis, comparison } \\
\text { with ideal working status }\end{array}$ & Various defects & F3 & D1 \\
\hline [162] & 2 accelerometers & $\mathrm{EH}, \mathrm{BP}$ & Statistical process control & Voids & F3 & D2 \\
\hline [185] & 2 accelerometers & $\mathrm{EH}, \mathrm{BP}$ & Support vector machine, neural network & Filament jam, warpage, material leakage & F3 & D2 \\
\hline [87] & 5 accelerometers & BC, AS & Neural network & Mechanical failure, axle failure & F3 & D2 \\
\hline
\end{tabular}

the effective nozzle diameter, which was used as a measure for nozzle clogging conditions. They observed that the amplitude of the vibration increased nonlinearly with decreasing effective nozzle diameter. The results of an analytical model for the theoretical determination of the amplitude exhibited good agreement with those of the experiments using both Bowden and direct extruders. In another research work [185] sensors were attached to both the extrusion head and build platform. This enabled the detection of part deformations and defective extruder conditions. The detection of defects in mechanical components of the MEX machine was solely investigated by Yen and Chuang [87].

\subsection{D vision}

The advantage of $3 \mathrm{D}$ vision compared to $2 \mathrm{D}$ vision is that height information can be captured. Table 5 indicates that nearly all of the publications address the monitoring of individual layers, in which comparison with different types of digital reference information was used for error detection.

If structured light or stereoscopic imaging systems are used, the sensors are rigidly aligned to the build platform [75, 76, 100, 186-191, 193]. Holzmond and Li [193] for example, used two five-megapixel cameras to create a stereoscopic imaging system. The viewing axes of the cameras were aligned perpendicular to the layers. To capture images of the layers, the extrusion head was moved out of the viewing axis by making it print a waste part parallel to the target part. After each layer, the extrusion head moved to the waste 
Table 5 Summary of publications on 3D vision

\begin{tabular}{|c|c|c|c|c|c|c|}
\hline References & Sensors & Ele & Data handling & Quality characteristics & Fun & Dev \\
\hline [186] & Camera, structured light & $\mathrm{L}$ & $\begin{array}{l}\text { Extracting sub-region features, comparison } \\
\text { with CAD model }\end{array}$ & Holes, bumps, curling & F3 & D2 \\
\hline [187] & 2 cameras, structured light & $\mathrm{L}$ & Deep learning & Process shifts & F3 & D2 \\
\hline$[100,188-191]$ & 2 cameras, structured light & $\mathrm{L}$ & Comparison with G-code & Geometric deviations & F3 & D2 \\
\hline$[154,155]$ & 2 cameras, structured light & $S$ & Texture analysis & Surface quality & F3 & D1 \\
\hline [192] & Camera, illumination & $\mathrm{L}$ & $\begin{array}{l}\text { Comparison with reference, artificial intel- } \\
\text { ligence control }\end{array}$ & Various defects & F4 & $\mathrm{P}$ \\
\hline [193] & 2 cameras, illumination & $\mathrm{L}$ & Comparison with G-code & Geometric deviations, holes, blobs & F3 & D2 \\
\hline$[75,76]$ & $3 \times 2$ cameras, illumination & $\mathrm{S}$ & Comparison with STL file & Geometric deviations & F3 & D2 \\
\hline [194] & 3D camera & $\mathrm{P}$ & Comparison with reference & Geometric deviations & $\mathrm{F} 4$ & $\mathrm{P}$ \\
\hline [195] & Laser triangulation & $\mathrm{L}$ & $\begin{array}{l}\text { Comparison with CAD model, measurement } \\
\text { of defects }\end{array}$ & Underfill, overfill & F3 & D2 \\
\hline [196] & Laser triangulation & $\mathrm{L}$ & Visualizing sensor data & Bead shape & F4 & D1 \\
\hline$[62]$ & Laser triangulation & $\mathrm{L}$ & Comparison with G-code & Underfill, overfill & $\mathrm{F} 4$ & $\mathrm{D} 2$ \\
\hline$[72,73]$ & Laser triangulation & $\mathrm{L}$ & $\begin{array}{l}\text { Comparison with nominal layer height, re- } \\
\text { slicing }\end{array}$ & Layer height, bead width & F4 & D2 \\
\hline [64] & Laser triangulation & $\mathrm{L}$ & $\begin{array}{l}\text { Comparison with reference, generating } \\
\text { modified path }\end{array}$ & Spatial bead position & F4 & D2 \\
\hline [197] & 2 laser triangulation & $\mathrm{L}$ & 2D comparison with G-code & Geometric deviations, voids & F3 & D2 \\
\hline [198] & n.a & $\mathrm{L}$ & Comparison with reference & Geometric deviations & F3 & $\mathrm{P}$ \\
\hline
\end{tabular}

part, creating a time window for image acquisition. A reference point cloud was generated from the G-code, which could be compared with the captured point cloud to detect defects. The approach was limited in that the system could only inspect materials with naturally textured surfaces.

In contrast, laser triangulation sensors record single height profiles. Therefore, a relative movement between the inspection object and sensor should be attained to generate a $3 \mathrm{D}$ point cloud from a large number of height profiles. Hence, the laser triangulation system is attached to the extrusion head of the MEX machine and can be moved over the layer surface [62, 64, 72, 73, 195-197].

Table 6 Summary of publications on acoustic emission monitoring

\begin{tabular}{|c|c|c|c|c|c|c|}
\hline References & Sensors & Ele & Data handling & Quality characteristics & Fun & Dev \\
\hline [199] & Acoustic emission & EH & Feature-based time domain analysis & Filament breakage & $\mathrm{F} 2$ & D2 \\
\hline [200] & Acoustic emission & EH & Frequency domain analysis & Extruder state & $\mathrm{F} 2$ & D2 \\
\hline [201] & Acoustic emission & $\mathrm{EH}$ & $\begin{array}{l}\text { Clustering by fast search and finding of } \\
\text { density peaks }\end{array}$ & Extruder state & F3 & D2 \\
\hline$[202,203]$ & Acoustic emission & EH & $\begin{array}{l}\text { Hidden semi-Markov model, support } \\
\text { vector machine }\end{array}$ & Extruder state & F3 & D2 \\
\hline$[74,204]$ & Acoustic emission & BP & $\begin{array}{l}\text { Hidden semi-Markov model, support vec- } \\
\text { tor machine, acoustic emission hits }\end{array}$ & Curling, detachment & F3 & D2 \\
\hline$[205,206]$ & Acoustic emission & BP & k-means clustering, neural network & First layer defects & F3 & D2 \\
\hline [207] & Audio recorder & $\mathrm{EH}, \mathrm{AS}$ & $\begin{array}{l}\text { Gradient boosting regression, logistic } \\
\text { regression classifier }\end{array}$ & Geometric deviations & F3 & D2 \\
\hline [208] & Microphone & $\mathrm{EH}, \mathrm{AS}$ & $\begin{array}{l}\text { Audio classifier for comparison with ideal } \\
\text { process }\end{array}$ & Infill pattern, fill density & F3 & D2 \\
\hline [209] & Microphone & $\mathrm{EH}, \mathrm{BC}, \mathrm{AS}$ & Neural network & $\begin{array}{l}\text { Nozzle offset height, fan activity, 3D } \\
\text { printer activity, door opening/closing, } \\
\text { axes movements }\end{array}$ & F3 & D2 \\
\hline [210] & Smartphone & $\mathrm{EH}, \mathrm{AS}$ & Comparison with ideal process & Malicious modified G-code & F3 & D2 \\
\hline
\end{tabular}


Fig. 9 Installation of an acoustic emission sensor attached to the extrusion head. Adapted by permission from Springer Nature: Springer Int. J. Adv. Manuf. Technol. [203], copyright 2016

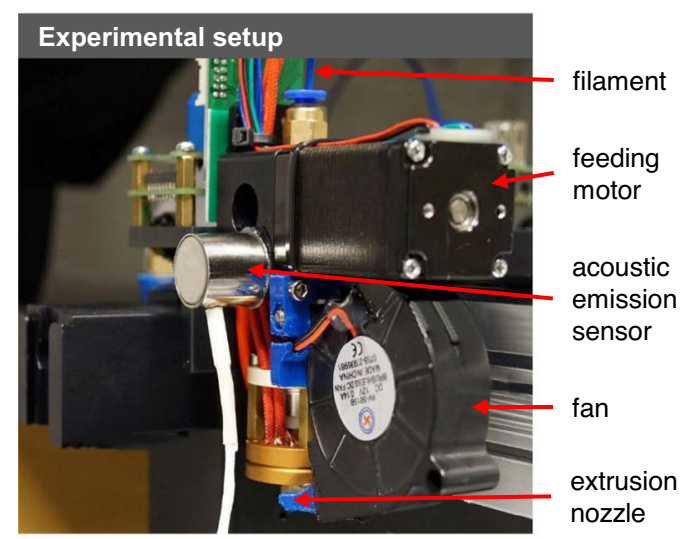

\subsection{Acoustic emission monitoring}

Acoustic emission monitoring can be used because various actuators and mechanical components of the 3D printer generate noise (Table 6). If anomalies occur, they will cause changes in the acoustic emissions. Many studies have used this sensor technology to monitor extrusion heads. For example, Wu et al. [203] attached an acoustic emission sensor to an extruder with vacuum grease. The mounting arrangement is depicted in Fig. 9. The state of the extruder was classified into the following using a hidden semi-Markov model: extruding without material, material loading/unloading, idle, and normal extruding. In validation experiments, a classification accuracy of more than $90 \%$ was achieved.

In another study [205, 206], a sensor mounted on the build platform next to the part could detect detachment of the part from the build platform and deformations. The defective part came into contact with the nozzle, which resulted in altered acoustic emissions. Moreover, recording devices can be placed next to the 3D printer [207-210]. Using this setup, Chhetri et al. [207] reconstructed the geometry of layers based on the acoustic emissions of the axes and motors. By comparing the reconstructed geometry with the original G-code, they were able to identify cyberattacks. Evaluation experiments demonstrated that a modified geometry of a quadcopter baseplate was detectable.

\subsection{Electrical quantities monitoring}

Table 7 lists all identified sources in the field of monitoring electrical quantities. The sensors used are often for monitoring motor currents. For example, the currents of the motors to push the filament through the extrusion head or to move the axes are measured. Nozzle blockages or incorrect axis movement cause changes in the motor current and can be evaluated. Kim et al. [211-213] observed that the motor current of an extruder is correlated with the level of extrusion pressure. The extrusion pressure depends on the size of the nozzle outlet and the distance between the nozzle and substrate. If the part is deformed and the distance to the nozzle outlet is reduced, or if a foreign object prevents the material from exiting, the pressure will increase and changes in the motor current will occur.

\subsection{Force and pressure monitoring}

Hitherto publications on force and pressure measurements focused on investigations of extrusion head elements (Table 8). Klar et al. [71] showed that the extrusion force in a piston-based extrusion device for processing ceramic, silicone, and acrylic pastes can be measured using a load cell. Force variations were directly related to the flow characteristics of the material. Other than the extrusion forces,

Table 7 Summary of publications on electrical quantities monitoring

\begin{tabular}{|c|c|c|c|c|c|c|}
\hline References & Sensors & Ele & Data handling & Quality characteristics & Fun & Dev \\
\hline [211-213] & Current & EH & $\begin{array}{l}\text { Graphical frequency } \\
\text { and time domain } \\
\text { analysis }\end{array}$ & Extrusion pressure, foreign objects, deformation & $\mathrm{F} 2$ & D2 \\
\hline [214] & Current & EH & Analytical model & Nozzle clogging conditions & F3 & D2 \\
\hline [215] & Current & EH, AS & $\begin{array}{l}\text { Similarity measure } \\
\text { with defect-free } \\
\text { reference }\end{array}$ & Sabotage attacks in G-code & F3 & D2 \\
\hline$[216,217]$ & Capacitive & $\mathrm{P}$ & n.a & Number of layers, holes & F1 & D1 \\
\hline [108] & Power & $\mathrm{EH}, \mathrm{AS}$ & Random forest & Infill structure voids, extrusion temperature & F3 & D2 \\
\hline
\end{tabular}


Table 8 Summary of publications on force and pressure monitoring

\begin{tabular}{|c|c|c|c|c|c|c|}
\hline References & Sensors & Ele & Data handling & Quality characteristics & Fun & Dev \\
\hline [71] & Load cell & $\mathrm{EH}$ & n.a & Piston force & $\mathrm{F} 1$ & D2 \\
\hline [218] & Load cell & FS & $\begin{array}{l}\text { Digital-twin, threshold } \\
\text { for defect detection }\end{array}$ & Filament amount in storage & F3 & D2 \\
\hline [219] & Force & $\mathrm{EH}$ & n.a & Contact force against the nozzle & F3 & $\mathrm{P}$ \\
\hline [69] & Force/torque & EH & $\begin{array}{l}\text { Visualization, threshold } \\
\text { for defect detection }\end{array}$ & Fiber pullout/shearing & F3 & D2 \\
\hline [220] & Pressure & EH & n.a & Pressure in the liquefier, material flow rate & $\mathrm{F} 4$ & $\mathrm{P}$ \\
\hline
\end{tabular}

Table 9 Summary of publications on other sensor technologies

\begin{tabular}{|c|c|c|c|c|c|c|}
\hline References & Sensors & Ele & Data handling & Quality characteristics & Fun & Dev \\
\hline$[221,222]$ & Fiber Bragg grating & $\mathrm{P}$ & Analysis of wavelength changes & Strain & $\mathrm{F} 2$ & D2 \\
\hline [223-225] & Fiber Bragg grating & $\mathrm{P}$ & Analysis of wavelength changes & Strain & $\mathrm{F} 2$ & D2 \\
\hline [226] & Fiber Bragg grating & $\mathrm{P}$ & Analysis of wavelength changes & Strain & $\mathrm{F} 2$ & D2 \\
\hline [227] & $1 / 2$ fiber Bragg grating & $\mathrm{P}$ & n.a & Strain, temperature & $\mathrm{F} 1$ & D2 \\
\hline [228] & Optical backscatter reflectometry & $\mathrm{P}$ & Analysis of frequency shifts & Strain, voids & $\mathrm{F} 2$ & D2 \\
\hline [229] & Ultrasonic & $\mathrm{P}$ & n.a & Infill structure & $\mathrm{F} 1$ & D1 \\
\hline$[230,231]$ & $1 / 2$ ultrasonic & $\mathrm{P}$ & n.a & $\begin{array}{l}\text { Fiber-scale print errors, bonding } \\
\text { strength, orientation of beads }\end{array}$ & $\mathrm{F} 1$ & D2 \\
\hline$[232,233]$ & 4 ultrasonic & $\mathrm{P}$ & $\begin{array}{l}\text { Comparison with ideal part, con- } \\
\text { trol feedback }\end{array}$ & Delamination, geometry & $\mathrm{F} 4$ & D1 \\
\hline [234] & $\begin{array}{l}\text { Ultrasonic, laser Doppler vibro- } \\
\text { meter }\end{array}$ & $\mathrm{L}$ & Data visualization & Foreign objects, holes & F1 & D2 \\
\hline$[235,236]$ & Optical encoder & FS & Calculation of filament movement & $\begin{array}{l}\text { Filament blockage/speed, lack of } \\
\text { filament }\end{array}$ & $\mathrm{F} 3$ & D2 \\
\hline [237] & Linear encoder & AS & Proportional-integral control & Position of axes & $\mathrm{F} 4$ & D2 \\
\hline [238] & Laser displacement & $\mathrm{L}$ & Comparison with CAD model & Geometric deviations & $\mathrm{F} 2$ & D2 \\
\hline [239] & Interferometry & $\mathrm{BP}$ & Calculation of surface curvature & Deformations & $\mathrm{F} 2$ & D2 \\
\hline [240] & Vibroacoustic & $\mathrm{BP}$ & Discrete wavelet transform & First layer adhesion & $\mathrm{F} 2$ & D2 \\
\hline [93] & 2 strain gauges & $\mathrm{BP}$ & Threshold analysis & Warping & $\mathrm{F} 3$ & D2 \\
\hline [208] & Gyroscopic & AS & Real-time visualization & Infill pattern, fill density & $\mathrm{F} 2$ & D2 \\
\hline [241] & Coordinate measuring machine & $\mathrm{P}$ & $\begin{array}{l}\text { Comparison with reference, adjust } \\
\text { process }\end{array}$ & Geometric deviations & F4 & $\mathrm{P}$ \\
\hline [242] & Split ring resonator probe & $\mathrm{P}$ & Generate 3D map of part & $\begin{array}{l}\text { Relative dielectric permittivity, } \\
\text { dimensions }\end{array}$ & $\mathrm{F} 2$ & D2 \\
\hline [243] & Velocimetry & $\mathrm{EH}, \mathrm{FS}$ & Controller & $\begin{array}{l}\text { Extrudate flow rate, filament feed } \\
\text { rate }\end{array}$ & $\mathrm{F} 4$ & $\mathrm{P}$ \\
\hline [244] & Magnetic & $\mathrm{FS}, \mathrm{BC}, \mathrm{AS}$ & n.a & $\begin{array}{l}\text { Door access, motor step losses, } \\
\text { build platform level, material } \\
\text { transport }\end{array}$ & $\mathrm{F} 1$ & D2 \\
\hline [245] & n.a & $\mathrm{L}$ & Re-slicing & Various defects & F4 & $\mathrm{P}$ \\
\hline
\end{tabular}

forces acting at the nozzle tip owing to the external effects of substrate defects can also be measured [219]. Furthermore, in the MEX of continuous fibers, fibers that are not fed at a sufficient rate by the delivery mechanism result in analyzable changes in forces. Exceedingly high forces, in turn, cause fiber pull-out and shearing [69].

\subsection{Other sensor technologies}

In this section, different sensor technologies with small numerical shares of publication in the literature are summarized (Table 9). In some publications, fiber Bragg grating sensors are presented as possible means of measuring strains. In such a system, the printing process is interrupted at a certain point and optical fibers are placed on the 
Fig. 10 Process monitoring with embedded optical fiber and schematic view of the cross-section. Left figure adapted from [224], copyright 2013, with permission from Elsevier. Right figures redrawn and adapted from [221], copyright 2016, with permission from Elsevier (Creative Commons license. https://creativecommons.org/ licenses/by-nc-nd/4.0)
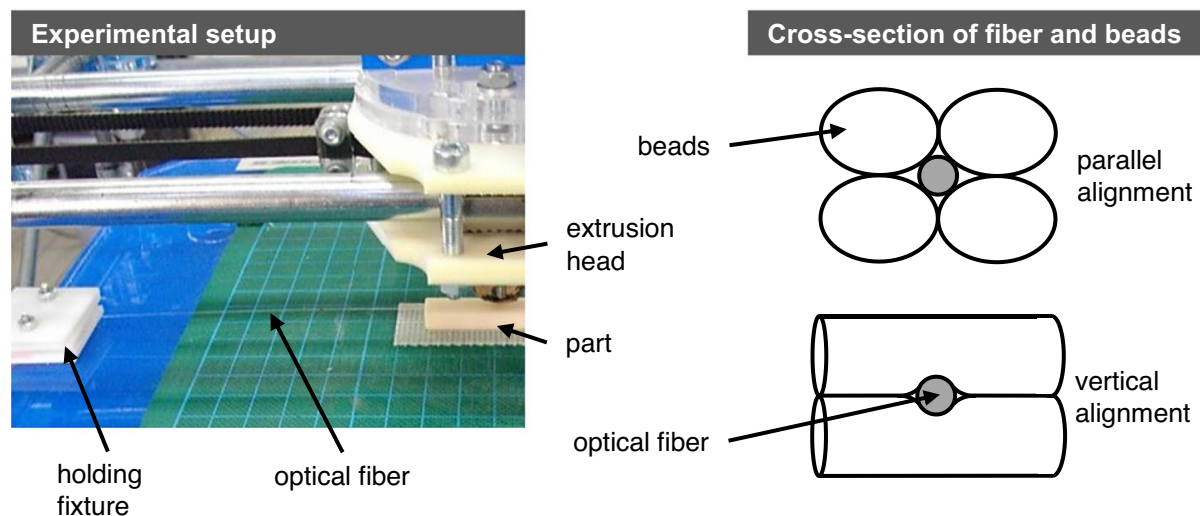

unfinished part. Subsequently, these are overprinted with additional material (Fig. 10). If deformations of the part and consequently of the optical fiber occur, they can be detected and analyzed [221-227]. Since the placement of the optical fibers as well as the properties of the surrounding material have an impact on the accuracy of the measurements, Falcetelli et al. [246] discussed and investigated different fiber embedding strategies.

Some research groups used ultrasonic sensors to analyze the part structures. Reflections of high-frequency pulses exerted onto the part were analyzed based on the duration until detection [229-233]. Another relevant approach is the use of encoders to determine the axis positions and to implement closed-loop control of the axis movement. This approach is considered state of the art within the NC machine industry [237]. It is also present in some MEX machines available for purchase [30].

The heterogeneity of monitoring systems prevented the further formation of clusters with similar functional principles. Therefore, the authors refer to individual publications for additional information.

\subsection{Sensor fusion technologies}

The fusion of data from multiple sensor technologies is a powerful method for monitoring a large number of features. Table 10 and Fig. 5 show that 2D vision and 3D vision are rarely used in combination with other sensor technologies. This is presumably due to the large information volume of the measurement data of the optical inspection systems. Additionally, optical measurement techniques are commonly used to inspect the quality characteristics of a part. In contrast, measurements that describe the condition of the $3 \mathrm{D}$ printer must be obtained via various routes to characterize the heterogeneous components of the machine.

An effective grouping of the identified monitoring systems is not possible. As an example, a monitoring system consisting of six thermocouples for temperature measurements at the extruder, at the build platform, and in ambient air is presented here. Furthermore, two sensors were used to measure the vibrations of the build platform and extrusion head. An infrared sensor measured the temperature of the build surface near the nozzle at the location at which the material was deposited. The authors explained that no additional benefit could be expected from using the thermocouples; therefore, only vibration and infrared sensors were used for process monitoring. The dimensional accuracy, surface roughness, and underfills could be determined [276-278]. The underfills were classified as "normal operation," "stringy extrusion," and "nozzle clogged." When producing a standard test artifact, the system achieved an accuracy of $97 \%$ for classifying into these three categories [276].

\section{What are the research gaps?}

\subsection{Key topics for sensor technology and data processing}

In a workshop of the National Institute of Standards and Technology, USA, the measurement science roadmap for polymer-based additive manufacturing was elaborated. Said roadmap specifies developments concerning measurement science required for the industrialization of additive manufacturing. For process monitoring, four prioritized roadmap topics (RT) were identified [13]:

- RT1: new in-situ imaging modalities

- RT2: real-time process measurement at required spatial and temporal resolution

- RT3: in-situ control and model integration

- RT4: big data analytics

A comparison of RT1 with the identified literary sources shows that the current research activity likewise focuses on the development of imaging modalities. From an industrial perspective, approaches that address the inspection of layers are particularly promising. Here, a single sensor module can 


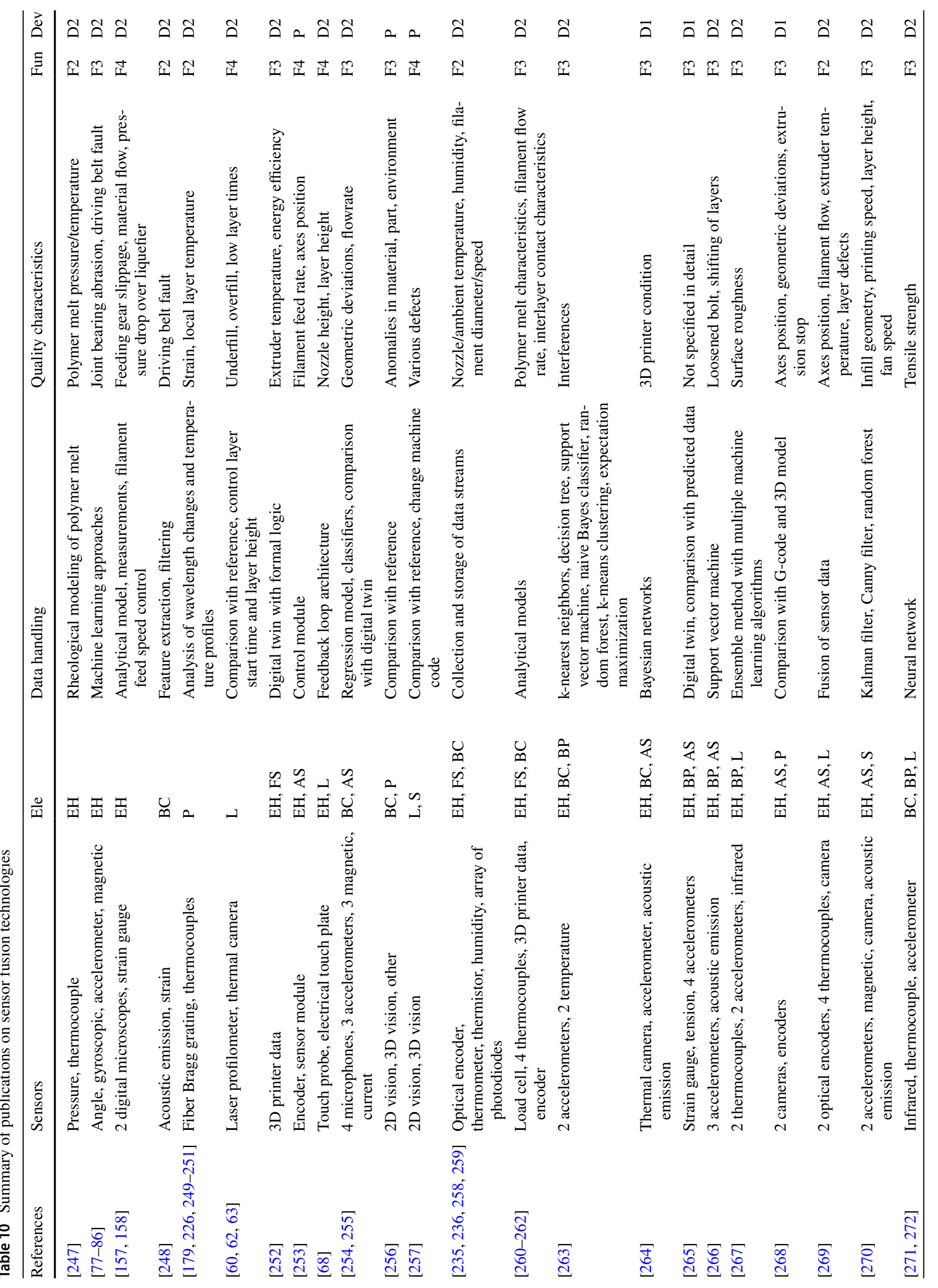




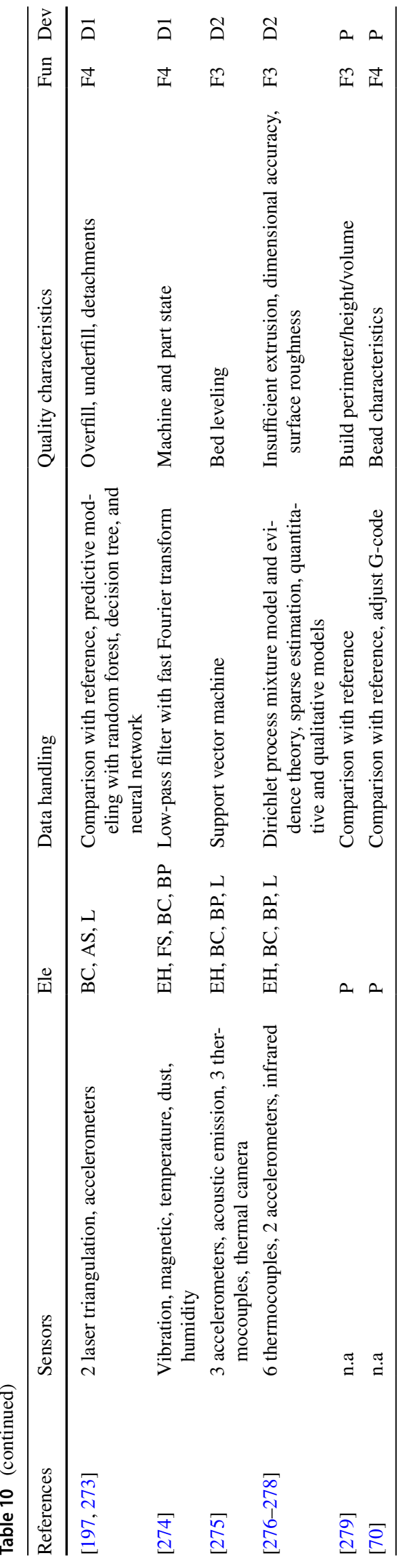

be utilized to inspect both the outer walls and inner structures of parts. Geometries and surface characteristics can be effectively inspected using 2D vision and 3D vision. Optical temperature measurements can be used to verify the thermal material properties. In addition to imaging techniques, monitoring of extrusion head conditions should be prioritized in future research because it is a key element of MEX systems. Measurements of current, vibrations, and acoustic signals are advantageous because the sensors can be installed with minimal effort. In contrast, force and pressure measurements require modifying the mechanical extrusion head components. However, this enables precise determination of the polymer melt conditions.

Regardless of the sensor technology, there is a fundamental necessity for research on integrating sensors into industrial MEX systems. New and improved sensor concepts that are designed for high ambient temperatures and large build volumes are required. Furthermore, efficient sensor modules, which can be realized in MEX machines despite restrictions due to moving machine parts and frame structures, must be developed.

The large number of patents on closed-loop control in Fig. 4 indicates that this topic is considered to be fundamentally important in the industry. High-performance measurement technology (RT2) is a prerequisite for these control loops (RT3). For the resolution of acquired data and speed of data processing, satisfactory results have already been achieved for some specific measurement tasks. This is demonstrated by the first controlled systems that adjust process parameters in sufficiently short periods and with adequate accuracy $[63,160,180]$. However, these systems require much improvement. For example, sensor technologies for detecting small voids or part contours in large-area, highresolution layer images at high speeds are not yet available. Furthermore, classifying monitoring systems use only a few classes; therefore, they have low resolutions. Moreover, the current closed-loop control is based on simple causal relationships. Mathematical models that describe complex relationships between several process parameters, control variables, and part properties have not yet been sufficiently researched.

Large and complex datasets generated by different sensor technologies and assignable to the field of big data analytics (RT4) were not used in the identified publications. Therefore, datasets with heterogeneous sensor data from several varying print jobs must be generated in the future to train robust inspection algorithms. The analysis of the literature has confirmed the significance of this subject by demonstrating that, owing to the complexity of the inspection task, only multi-sensor approaches enable comprehensive monitoring of the MEX process. 


\subsection{Rarely examined quality characteristics}

Aside from the specific wear-prone components of the 3D printer, all properties of the parts are, in principle, relevant to MEX monitoring. The requirements for a part can be divided into mechanical and geometrical requirements, surface requirements, and requirements for feedstock materials [280].

The focus of the current research is on part geometries and surface properties in terms of overfill and underfill. However, measurements of surface roughness were addressed by only two research projects [267, 276-278]. The measurement of mechanical properties is another important aspect that was investigated by merely two works as well: Bartolai et al. [173, 174] and Zhang et al. [271, 272] addressed the prediction of tensile strengths. Means of inspecting material characteristics were not considered in any publication. The monitoring of these quality characteristics, which the current research only addresses to a limited extent, represents a gap for future research.

\subsection{Variety and complexity of monitored parts}

A challenge with MEX monitoring is the required flexibility [14]. Varying and often complex part geometries are manufactured in very small batches. Furthermore, many different materials can be processed. Therefore, the extent to which the flexibility of the MEX is reflected in the reviewed monitoring systems was investigated. The properties of parts manufactured in projects with the aim of process monitoring for quality assessment were analyzed considering the aspects listed below:

- complexity of geometries (simple or complex),

- number of different geometries,

- materials used, and

- number of different materials used.

The analysis showed that $19.3 \%$ of the projects contained an investigation of complex part geometries, 55.9\% monitored simple geometries, and $24.8 \%$ did not specify the geometry. Simple geometries include, among others, cuboids, cylinders, or single material beads. In contrast, the complex geometries describe a prosthesis or valve housing, for example. For the number of different geometries per project, the authors observed that $47.6 \%$ of the projects investigated one geometry, $12.4 \%$ two geometries, and $7.6 \%$ three geometries. More than three geometries were analyzed in only $8.3 \%$ of the projects, while $24.1 \%$ did not specify the geometry.

$40.7 \%$ of works did not specify the material. Polylactide (PLA) and acrylonitrile butadiene styrene (ABS) were used in $34.5 \%$ and $26.9 \%$ of the projects, respectively.
Composite materials were used in $6.2 \%$, polycarbonate in $2.1 \%$, and ceramic materials in $1.4 \%$ of the projects. Other materials had a proportion of $<1 \%$ each. In $74.4 \%$ of the projects that specify the material, only one type of material was investigated, while $19.8 \%$ of the projects used two, $4.7 \%$ three, and $1.2 \%$ four different materials. Projects that employed more than one material consistently produced different parts separately from just one material each. Only one publication [252] stated that the part was made from PLA and one additional support material.

The results show that projects with high complexity and variation in part geometries and materials are strongly underrepresented in the dataset. The analyzed monitoring systems tend to monitor manufacturing processes for simple geometries and small numbers of varying parts. Regarding the materials used, ABS and PLA dominate the research projects, the number of different materials per project is oftentimes low and multiple material parts are only considered to a minor extent. However, complex geometries and cost-intensive materials (e.g., metal-filled or fiber-reinforced plastics) are particularly suitable for process monitoring, because this is where the economic efficiency of the inspection system is most easily achieved. Therefore, there is considerable potential for further research regarding the monitoring of various complex parts.

\subsection{Standardization}

Owing to the novelty of the technology and the diversity of the topic, standardization in the field of additive manufacturing is still in its early stages. There are only a limited number of standards for the specification of part properties and non-destructive testing methods [14, 28]. Analysis of the identified publications has also shown that no consistent definitions are used for quality characteristic names, feature specifications, and tolerance limits.

As a first step towards standardization, ISO/ASTM 52901 [281] basically describes how part characteristics, tolerances, and test methods are to be defined between the customer and the supplier. With regard to process monitoring, the decision of whether a process variation represents a defect or not is particularly crucial [282]. Future projects can use the draft standard ISO/ASTM DIS 52924 [46] to specify these tolerance limits, as the document defines the quality levels of MEX plastic parts in terms of relative part density, dimensional accuracy, and mechanical properties for an entire part. However, to analyze small defects with high spatial resolution, MEX-specific characteristics must be considered. For example, unsupported bridging results in changes in geometric tolerances. 
For the description of part characteristics, general standards such as the geometrical product specification matrix model [283] are applicable. Here, surface imperfections in the layer structure can be characterized according to the ISO 8785 standard, which specifies the nomenclature and characteristics of these irregularities [284]. Furthermore, standards for conventional non-destructive testing methods can be adapted to the process monitoring of MEX [14]

\section{Conclusion}

Monitoring of MEX during the manufacturing process is crucial for the industrial use of this technology. The publication activity in this field is increasing. This clearly indicates that the subject is significant. The wide range of sensor technologies used and quality characteristics monitored demonstrate that the existing monitoring systems have been researched at many functional levels. However, for the widespread utilization of monitoring systems, further optimization is required.

The strength of this review is in its systematic approach to the literature search and the large dataset used. The state of knowledge is presented comprehensively, and research gaps are identified. Limitations exist because of the possibility that the literature evaluation and identification of future priorities are affected by the individual perspectives of the authors. For a highly differentiated analysis of the publications, future reviews may also include more systematic and detailed assessments of the results and quality of studies.

Author contributions Alexander Oleff: Conceptualization, Methodology, Formal analysis, Investigation, Data Curation, Writing - Original Draft, Writing - Review \& Editing, Visualization, Project administration, Funding acquisition Benjamin Küster: Writing - Review \& Editing, Project administration, Funding acquisition Malte Stonis: Writing - Review \& Editing, Project administration, Funding acquisition Ludger Overmeyer: Conceptualization, Methodology, Writing - Review \& Editing, Supervision, Funding acquisition

Funding This work is part of the research project $20714 \mathrm{~N}$ of the Research Community for Quality (FQS), August-Schanz-Str. 21A, 60433 Frankfurt/Main and has been funded by the AiF within the program for sponsorship by Industrial Joint Research (IGF) of the German Federal Ministry of Economic Affairs and Energy based on an enactment of the German Parliament. Open Access funding enabled and organized by Projekt DEAL.

Open Access This article is licensed under a Creative Commons Attribution 4.0 International License, which permits use, sharing, adaptation, distribution and reproduction in any medium or format, as long as you give appropriate credit to the original author(s) and the source, provide a link to the Creative Commons licence, and indicate if changes were made. The images or other third party material in this article are included in the article's Creative Commons licence, unless indicated otherwise in a credit line to the material. If material is not included in the article's Creative Commons licence and your intended use is not permitted by statutory regulation or exceeds the permitted use, you will need to obtain permission directly from the copyright holder. To view a copy of this licence, visit http://creativecommons.org/licenses/by/4.0/.

\section{References}

1. Wohlers T, Campbell I, Diegel O et al (2018) Wohlers Report 2018. 3D printing and additive manufacturing state of the industry: Annual Worldwide Progress Report. Wohlers Associates Inc, Fort Collins

2. Yi L, Gläßner C, Aurich JC (2019) How to integrate additive manufacturing technologies into manufacturing systems successfully: a perspective from the commercial vehicle industry. J Manuf Syst 53:195-211. https://doi.org/10.1016/j.jmsy.2019. 09.007

3. Najmon JC, Raeisi S, Tovar A (2019) Review of additive manufacturing technologies and applications in the aerospace industry. In: Froes F, Boyer R (eds) Additive Manufacturing for the Aerospace Industry. Elsevier, Amsterdam , pp 7-31

4. Javaid M, Haleem A (2018) Additive manufacturing applications in medical cases. A literature based review. Alexandria J Med 54:411-422. https://doi.org/10.1016/j.ajme.2017.09.003

5. Klotz UE, Tiberto D, Held F (2017) Optimization of 18-karat yellow gold alloys for the additive manufacturing of jewelry and watch parts. Gold Bull 50:111-121. https://doi.org/10.1007/ s13404-017-0201-4

6. Bos F, Wolfs R, Ahmed Z et al (2016) Additive manufacturing of concrete in construction: potentials and challenges of 3D concrete printing. Virtual Phys Prototyp 11:209-225. https://doi.org/ 10.1080/17452759.2016.1209867

7. Bacciaglia A, Ceruti A, Liverani A (2019) Evaluation of 3D printed mouthpieces for musical instruments. Rapid Prototyp J 26:577-584. https://doi.org/10.1108/RPJ-07-2019-0187

8. Bloomfield M, Borstrock S (2018) Modeclix. The additively manufactured adaptable textile. Mater Today Commun 16:212216. https://doi.org/10.1016/j.mtcomm.2018.04.002

9. Ngo TD, Kashani A, Imbalzano G et al (2018) Additive manufacturing (3D printing): a review of materials, methods, applications and challenges. Compos Part B Eng 143:172-196. https://doi. org/10.1016/j.compositesb.2018.02.012

10. Energetics Incorporated, National Institute of Standards and Technology (2013) Measurement Science Roadmap for MetalBased Additive Manufacturing. National Institute of Standards and Technology (NIST), Columbia MD

11. Kim H, Lin Y, Tseng T-LB (2018) A review on quality control in additive manufacturing. Rapid Prototyp J 24:645-669. https://doi.org/10.1108/RPJ-03-2017-0048

12. Huang T, Wang S, He K (2015) Quality control for fused deposition modeling based additive manufacturing: Current research and future trends. 2015 First Int Conf Reliab Syst Eng (ICRSE). https://doi.org/10.1109/ICRSE.2015.7366500

13. Pellegrino J, Makila T, McQueen S et al (2016) Measurement Science Roadmap for Polymer-Based Additive Manufacturing. National Institute of Standards and Technology (NIST), Columbia

14. Lu QY, Wong CH (2018) Additive manufacturing process monitoring and control by non-destructive testing techniques: challenges and in-process monitoring. Virtual Phys Prototyp 13:39-48. https://doi.org/10.1080/17452759.2017.1351201 
15. Vyavahare S, Teraiya S, Panghal D et al (2020) Fused deposition modelling: a review. Rapid Prototyp J 26:176-201. https:// doi.org/10.1108/RPJ-04-2019-0106

16. Leach RK, Bourell D, Carmignato S et al (2019) Geometrical metrology for metal additive manufacturing. CIRP Ann Manuf Technol 68:677-700. https://doi.org/10.1016/j.cirp.2019.05. 004

17. Chauveau D (2018) Review of NDT and process monitoring techniques usable to produce parts by welding or additive manufacturing. Weld World 62:1097-1118. https://doi.org/10.1007/ s40194-018-0609-3

18. Albakri MI, Sturm LD, Williams CB et al (2017) Impedancebased non-destructive evaluation of additively manufactured parts. Rapid Prototyp J 23:589-601. https://doi.org/10.1108/ RPJ-03-2016-0046

19. ISO/ASTM DIS 52900 (2018) Additive manufacturing - General principles - Terminology

20. Liu W-W, Tang Z-J, Liu X-Y et al (2017) A review on in-situ monitoring and adaptive control technology for laser cladding remanufacturing. Procedia CIRP 61:235-240. https://doi.org/10. 1016/j.procir.2016.11.217

21. Xia C, Pan Z, Polden J et al (2020) A review on wire arc additive manufacturing: Monitoring, control and a framework of automated system. J Manuf Syst 57:31-45. https://doi.org/10.1016/j. jmsy.2020.08.008

22. Mani M, Lane BM, Donmez MA et al (2017) A review on measurement science needs for real-time control of additive manufacturing metal powder bed fusion processes. Int J Prod Res 55:1400-1418. https://doi.org/10.1080/00207543.2016.1223378

23. Yan Z, Liu W, Tang Z et al (2018) Review on thermal analysis in laser-based additive manufacturing. Opt Laser Technol 106:427441. https://doi.org/10.1016/j.optlastec.2018.04.034

24. Chua ZY, Ahn IH, Moon SK (2017) Process monitoring and inspection systems in metal additive manufacturing: status and applications. Int J Precis Eng Manuf Green Technol 4:235-245. https://doi.org/10.1007/s40684-017-0029-7

25. Everton SK, Hirsch M, Stravroulakis P et al (2016) Review of in-situ process monitoring and in-situ metrology for metal additive manufacturing. Mater Des 95:431-445. https://doi.org/10. 1016/j.matdes.2016.01.099

26. Tapia G, Elwany A (2014) A review on process monitoring and control in metal-based additive manufacturing. J Manuf Sci Eng . https://doi.org/10.1115/1.4028540

27. Grasso M, Colosimo BM (2017) Process defects and in situ monitoring methods in metal powder bed fusion: a review. Meas Sci Technol. https://doi.org/10.1088/1361-6501/aa5c4f

28. Vora HD, Sanyal S (2020) A comprehensive review: metrology in additive manufacturing and 3D printing technology. Prog Addit Manuf. https://doi.org/10.1007/s40964-020-00142-6

29. Charalampous P, Kostavelis I, Tzovaras D (2020) Non-destructive quality control methods in additive manufacturing: a survey. Rapid Prototyp J 26:777-790. https://doi.org/10.1108/ RPJ-08-2019-0224

30. Mercado Rivera FJ, Rojas Arciniegas AJ (2020) Additive manufacturing methods: techniques, materials, and closed-loop control applications. Int J Adv Manuf Technol 109:17-31. https://doi. org/10.1007/s00170-020-05663-6

31. Honarvar F, Varvani-Farahani A (2020) A review of ultrasonic testing applications in additive manufacturing: Defect evaluation, material characterization, and process control. Ultrasonics 108:106227. https://doi.org/10.1016/j.ultras.2020.106227

32. Goh GD, Sing SL, Yeong WY (2020) A review on machine learning in 3D printing: applications, potential, and challenges. Artif Intell Rev. https://doi.org/10.1007/s10462-020-09876-9
33. Meng L, McWilliams B, Jarosinski W et al (2020) Machine learning in additive manufacturing: a review. JOM 72:23632377. https://doi.org/10.1007/s11837-020-04155-y

34. Razvi SS, Feng S, Narayanan A et al (2019) A review of machine learning applications in additive manufacturing. Proc ASME 2019 Int Des Eng Tech Conf Comput Inf Eng Conf. https://doi. org/10.1115/DETC2019-98415

35. Gibson I, Rosen D, Stucker B et al (2021) Chapter 6 - Material Extrusion. In: Gibson I, Rosen D, Stucker B et al (eds) Additive Manufacturing Technologies, 3rd edn. Springer, Cham, pp 171-202

36. Gonzalez-Gutierrez J, Cano S, Schuschnigg S et al (2018) Additive manufacturing of metallic and ceramic components by the material extrusion of highly-filled polymers: a review and future perspectives. Materials. https://doi.org/10.3390/ma11050840

37. Kampker A, Triebs J, Kawollek S et al (2019) Review on machine designs of material extrusion based additive manufacturing (AM) systems - status-Quo and potential analysis for future AM systems. Procedia CIRP 81:815-819. https://doi.org/ 10.1016/j.procir.2019.03.205

38. Anandkumar R, Babu SR (2019) FDM filaments with unique segmentation since evolution: a critical review. Prog Addit Manuf 4:185-193. https://doi.org/10.1007/s40964-018-0069-8

39. Mohan N, Senthil P, Vinodh S et al (2017) A review on composite materials and process parameters optimisation for the fused deposition modelling process. Virtual Phys Prototyp 12:47-59. https://doi.org/10.1080/17452759.2016.1274490

40. Leary M (2020) Chapter 4 - Detail DFAM. In: Leary M (ed) Additive manufacturing materials and technologies: design for additive manufacturing. Elsevier, Amsterdam , pp 91-122

41. Nieto DM, Molina SI (2019) Large-format fused deposition additive manufacturing: a review. Rapid Prototyp J 26:793-799. https://doi.org/10.1108/RPJ-05-2018-0126

42. Franchetti M, Kress C (2017) An economic analysis comparing the cost feasibility of replacing injection molding processes with emerging additive manufacturing techniques. Int J Adv Manuf Technol 88:2573-2579. https://doi.org/10.1007/ s00170-016-8968-7

43. Davies S (2021) Stratasys to supply 3D printed parts to several additional aircraft families as Airbus renews contract. TCT Magazine. https://www.tctmagazine.com/additive-manufactur ing-3d-printing-news/stratasys-3d-printed-parts-several-airbusaircraft-families. Accessed 18 Apr 2021

44. Mohamed OA, Masood SH, Bhowmik JL (2015) Optimization of fused deposition modeling process parameters. A review of current research and future prospects. Adv Manuf 3:42-53. https:// doi.org/10.1007/s40436-014-0097-7

45. Rahim TNAT, Abdullah AM, Md Akil H (2019) Recent developments in fused deposition modeling-based 3D printing of polymers and their composites. Polym Rev 59:589-624. https://doi. org/10.1080/15583724.2019.1597883

46. ISO/ASTM DIS 52924 (2020) Additive manufacturing - Qualification principles - Classification of part properties for additive manufacturing of polymer parts

47. Chen RK, Lo TT, Chen L et al (2015) Nano-CT characterization of structural voids and air bubbles in fused deposition modeling for additive manufacturing. Proc ASME Int Manuf Sci Eng Conf. https://doi.org/10.1115/MSEC2015-9462

48. Turner BN, Strong R, A. Gold S, (2014) A review of melt extrusion additive manufacturing processes: I. Process design and modeling. Rapid Prototyp J 20:192-204. https://doi.org/10.1108/ RPJ-01-2013-0012

49. Bochmann L, Bayley C, Helu M et al (2015) Understanding error generation in fused deposition modeling. Surf Topogr Metrol Prop. https://doi.org/10.1088/2051-672X/3/1/014002 
50. Hsiang Loh G, Pei E, Gonzalez-Gutierrez J et al (2020) An overview of material extrusion troubleshooting. Appl Sci 10:4776. https://doi.org/10.3390/app10144776

51. Turner BN, Gold SA (2015) A review of melt extrusion additive manufacturing processes: II. Materials, dimensional accuracy, and surface roughness. Rapid Prototyp J 21:250-261. https://doi. org/10.1108/RPJ-02-2013-0017

52. Jafari MA, Han W, Mohammadi F et al (2000) A novel system for fused deposition of advanced multiple ceramics. Rapid Prototyp J 6:161-175. https://doi.org/10.1108/13552540010337047

53. Sood AK, Ohdar RK, Mahapatra SS (2012) Experimental investigation and empirical modelling of FDM process for compressive strength improvement. J Adv Res 3:81-90. https://doi.org/10. 1016/j.jare.2011.05.001

54. Jagenteufel R, Hofstätter T, Kamleitner F et al (2017) Rheology of high melt strength polypropylene for additive manufacturing. Adv Mater Lett 8:712-716. https://doi.org/10.5185/amlett.2017. 1450

55. Beran T, Mulholland T, Henning F et al (2018) Nozzle clogging factors during fused filament fabrication of spherical particle filled polymers. Addit Manuf 23:206-214. https://doi.org/10. 1016/j.addma.2018.08.009

56. Grant MJ, Booth A (2009) A typology of reviews: an analysis of 14 review types and associated methodologies. Health Info Libr J 26:91-108. https://doi.org/10.1111/j.1471-1842.2009.00848.x

57. Booth A, Sutton A, Papaioannou D (2016) Systematic approaches to a successful literature review, 1st edn. Sage Publications, London

58. Sutjipto S, Tish D, Paul G et al (2019) Towards visual feedback loops for robot-controlled additive manufacturing. In: Willmann J, Block P, Hutter M et al (eds) Robotic Fabrication in Architecture, Art and Design 2018, vol 21. Springer, Cham, pp 85-97

59. MacDonald E, Burden E, Walker J et al (2017) Spatial frequency analysis for improved quality in big area additive manufacturing (BAAM). Proc ASME 2017 Int Mech Eng Congr Expo. https:// doi.org/10.1115/IMECE2017-70630

60. Borish M, Post BK, Roschli A et al (2019) In-situ thermal imaging for single layer build time alteration in large-scale polymer additive manufacturing. Procedia Manuf 34:482-488. https://doi. org/10.1016/j.promfg.2019.06.202

61. Choo K, Friedrich B, Daugherty T et al (2019) Heat retention modeling of large area additive manufacturing. Addit Manuf 28:325-332. https://doi.org/10.1016/j.addma.2019.04.014

62. Borish M, Post BK, Roschli A et al (2019) Defect Identification and Mitigation Via Visual Inspection in Large-Scale Additive Manufacturing. JOM 71:893-899. https://doi.org/10.1007/ s11837-018-3220-6

63. Borish M, Post BK, Roschli A et al (2020) Real-Time Defect Correction in Large-Scale Polymer Additive Manufacturing via Thermal Imaging and Laser Profilometer. Procedia Manuf 48:625-633. https://doi.org/10.1016/j.promfg.2020.05.091

64. Armstrong AA, Norato J, Alleyne AG et al (2020) Direct process feedback in extrusion-based 3D bioprinting. Biofabrication. https://doi.org/10.1088/1758-5090/ab4d97

65. Wasserfall F, Ahlers D, Hendrich N (2019) Optical in-situ verification of 3D-printed electronic circuits. IEEE 15th Int Conf Autom Sci and Eng (CASE). https://doi.org/10.1109/COASE. 2019.8842835

66. Friedrich L, Begley M (2018) In situ characterization of lowviscosity direct ink writing: Stability, wetting, and rotational flows. J Colloid Interface Sci 529:599-609. https://doi.org/10. 1016/j.jcis.2018.05.110

67. Friedrich L, Begley M (2019) In situ digital image analysis in direct ink writing. In: Seppala JE, Kotula AP, Snyder CR (eds) Polymer-Based Additive Manufacturing: Recent Developments, vol 1315. American Chemical Society, Washington, pp 131-149
68. Hardin JO, Grabowski CA, Lucas M et al (2019) All-printed multilayer high voltage capacitors with integrated processing feedback. Addit Manuf 27:327-333. https://doi.org/10.1016/j. addma.2019.02.011

69. DeBacker W, Sinkez P, Chhabra I et al (2020) In-process monitoring of continuous fiber additive manufacturing through force/ torque sensing on the nozzle. AIAA SciTech Forum. https://doi. org/10.2514/6.2020-1632

70. Stockett RC, Tyler KL, Alfson BL et al (2018) Systems and methods for controlling additive manufacturing. US Patent 2018/0065307A1

71. Klar V, Pearce JM, Kärki P et al (2019) Ystruder: Open source multifunction extruder with sensing and monitoring capabilities. HardwareX. https://doi.org/10.1016/j.ohx.2019.e00080

72. Magnoni P, Rebaioli L, Fassi I et al (2017) Robotic AM System for Plastic Materials: Tuning and On-line Adjustment of Process Parameters. Procedia Manuf 11:346-354. https://doi.org/ 10.1016/j.promfg.2017.07.117

73. Rebaioli L, Magnoni P, Fassi I et al (2019) Process parameters tuning and online re-slicing for robotized additive manufacturing of big plastic objects. Robot Comput Integr Manuf 55:55-64. https://doi.org/10.1016/j.rcim.2018.07.012

74. Li F, Yu Z, Shen X et al (2019) Status recognition for fused deposition modeling manufactured parts based on acoustic emission. E3S Web Conf 95. https://doi.org/10.1051/e3sconf/20199501005

75. Nuchitprasitchai S, Roggemann M, Pearce JM (2017) Factors effecting real-time optical monitoring of fused filament 3D printing. Prog Addit Manuf 2:133-149. https://doi.org/10.1007/ s40964-017-0027-x

76. Nuchitprasitchai S, Roggemann M, Pearce J (2017) Three hundred and sixty degree real-time monitoring of 3-D printing using computer analysis of two camera views. F Manuf Mater Process 1:2. https://doi.org/10.3390/jmmp1010002

77. He K, Yang Z, Bai Y et al (2018) Intelligent fault diagnosis of delta 3D printers using attitude sensors based on support vector machines. Sensors. https://doi.org/10.3390/s18041298

78. Zhang S, Sun Z, Long J et al (2019) Dynamic condition monitoring for 3D printers by using error fusion of multiple sparse autoencoders. Comput Ind 105:164-176. https://doi.org/10.1016/j. compind.2018.12.004

79. Guo J, Wu J, Sun Z et al (2019) Fault diagnosis of delta 3D Printers Using Transfer Support Vector Machine With Attitude Signals. IEEE Access 7:40359-40368. https://doi.org/10.1109/ ACCESS.2019.2905264

80. He K, Zeng L, Shui Q et al (2019) Low-cost and Small-sample Fault Diagnosis for 3D Printers Based on Echo State Networks. Progn Syst Health Manag Conf (PHM-Qingdao). https://doi.org/ 10.1109/PHM-Qingdao46334.2019.8942894

81. Zhang S, He K, Cabrera D et al (2019) Transmission condition monitoring of 3D printers based on the echo state network. Appl Sci 9:3058. https://doi.org/10.3390/app9153058

82. Li C, Cabrera D, Sancho F et al (2021) Fusing convolutional generative adversarial encoders for 3D printer fault detection with only normal condition signals. Mech Syst Signal Process. https://doi.org/10.1016/j.ymssp.2020.107108

83. Long J, Sun Z, Li C et al (2020) A novel sparse echo autoencoder network for data-driven fault diagnosis of delta 3-D printers. IEEE Trans Instrum Meas 69:683-692. https://doi.org/10.1109/ TIM.2019.2905752

84. Long J, Zhang S, Li C (2020) Evolving Deep Echo State Networks for Intelligent Fault Diagnosis. IEEE Trans Ind Inform 16:4928-4937. https://doi.org/10.1109/tii.2019.2938884

85. Zhang S, Sun Z, Li C et al (2020) Deep hybrid state network with feature reinforcement for intelligent fault diagnosis of delta 3-D printers. IEEE Trans Ind Inform 16:779-789. https://doi.org/10. 1109/TII.2019.2920661 
86. Zhang S, Duan X, Li C et al (2021) Pre-classified reservoir computing for the fault diagnosis of 3D printers. Mech Syst Signal Process. https://doi.org/10.1016/j.ymssp.2020.106961

87. Yen C-T, Chuang P-C (2019) Application of a neural network integrated with the internet of things sensing technology for 3D printer fault diagnosis. Microsyst Technol. https://doi.org/10. 1007/s00542-019-04323-4

88. Wang Y, Huang J, Wang Y et al (2020) A CNN-based Adaptive Surface Monitoring System for Fused Deposition Modeling. IEEE ASME Trans Mechatron. https://doi.org/10.1109/TMECH. 2020.2996223

89. Kutzer MD, DeVries LD, Blas CD (2018) Part monitoring and quality assessment of conformal additive manufacturing using image reconstruction. Proc ASME 2018 Int Des Eng Tech Conf Comput Inf Eng Conf 5B. https://doi.org/10.1115/DETC2 018-85370

90. Shen H, Sun W, Fu J (2019) Multi-view online vision detection based on robot fused deposit modeling 3D printing technology. Rapid Prototyp J 25:343-355. https://doi.org/10.1108/ RPJ-03-2018-0052

91. Shen H, Du W, Sun W et al (2020) Visual detection of surface defects based on self-feature comparison in robot 3-D printing. Appl Sci. https://doi.org/10.3390/app10010235

92. Chen Z, Horowitz R (2019) Vision-assisted arm motion planning for freeform 3D Printing. 2019 Am Control Conf (ACC):42044209. https://doi.org/10.23919/ACC.2019.8814699

93. Jin Z, Zhang Z, Gu GX (2020) Automated real-time detection and prediction of interlayer imperfections in additive manufacturing processes using artificial intelligence. Adv Intell Syst. https://doi. org/10.1002/aisy.201900130

94. Jeong H, Kim M, Park B et al (2017) Vision-Based Real-Time Layer Error Quantification for Additive Manufacturing. Proc ASME 2017 12th Int Manuf Sci Eng Conf. https://doi.org/10. 1115/MSEC2017-2991

95. Prakash SKA, Mahan T, Williams G et al (2020) Detection of System Compromise in Additive Manufacturing Using Video Motion Magnification. J Mech Des. https://doi.org/10.1115/1. 4045547

96. Makagonov NG, Blinova EM, Bezukladnikov II (2017) Development of visual inspection systems for 3D printing. 2017 IEEE Conf Russ Young Res Electr Electron Eng (EIConRus):1463-1465. https://doi.org/10.1109/EIConRus.2017.79108 49

97. Narayanan BN, Beigh K, Loughnane G et al (2019) Support vector machine and convolutional neural network based approaches for defect detection in fused filament fabrication. Proc SPIE: Appl Mach Learn. https://doi.org/10.1117/12.2524915

98. Zhang Z, Fidan I (2019) Failure detection of fused filament fabrication via deep learning. Proc 30th Annu Int Solid Free Fabr Symp:2156-2164

99. Kim C, Hillstrom A, Coronel J et al (2018) Design of air cooling housing for image sensors using additive manufacturing technology. 2018 Int Conf Inf Commun Technol Robot (ICTROBOT):1-4. https://doi.org/10.1109/ICT-ROBOT.2018.85498 91

100. Preissler M, Zhang C, Rosenberger M et al (2017) Platform for 3D inline process control in additive manufacturing. Proc SPIE Opt Meas Syst Ind Insp X. https://doi.org/10.1117/12.2270493

101. Malik A, Lhachemi H, Ploennigs J et al (2019) An application of 3D model reconstruction and augmented reality for real-time monitoring of additive manufacturing. Procedia CIRP 81:346351. https://doi.org/10.1016/j.procir.2019.03.060

102. Straub J (2017) 3D printing cybersecurity: Detecting and preventing attacks that seek to weaken a printed object by changing fill level. Proc SPIE Dimens Opt Metrol Insp Pract Appl VI. https:// doi.org/10.1117/12.2264575
103. Straub J (2017) Identifying positioning-based attacks against 3D printed objects and the 3D printing process. Proc SPIE Pattern Recognit Track XXVIII. https://doi.org/10.1117/12.2264671

104. Wu M, Phoha VV, Moon YB et al (2016) Detecting malicious defects in 3D printing process using machine learning and image classification. Proc ASME 2016 Int Mech Eng Congre Expo. https://doi.org/10.1115/IMECE2016-67641

105. Wu M, Song Z, Moon YB (2019) Detecting cyber-physical attacks in CyberManufacturing systems with machine learning methods. J Intell Manuf 30:1111-1123. https://doi.org/10.1007/ s10845-017-1315-5

106. Wu M, Moon YB (2020) Alert correlation for detecting cybermanufacturing attacks and intrusions. J Comput Inf Sci Eng. https://doi.org/10.1115/1.4044208

107. Hurd S, Camp C, White J (2015) Quality assurance in additive manufacturing through mobile computing. Int Conf Mob Comput Appl Serv:203-220. https://doi.org/10.1007/978-3-319-29003-4_ 12

108. Wu M, Song J, Lucas Lin LW et al (2018) Establishment of intrusion detection testbed for CyberManufacturing systems. Procedia Manuf 26:1053-1064. https://doi.org/10.1016/j.promfg.2018.07. 142

109. Wang S, Huang T, Hou T (2017) Statistical Process Control in Fused Deposition Modeling based on Tanimoto similarity of uniform surface images of product. 2017 2nd Int Conf Reliab Syst Eng (ICRSE). https://doi.org/10.1109/ICRSE.2017.8030806

110. Huang T, Wang S, Yang S et al (2020) Statistical process monitoring in a specified period for the image data of fused deposition modeling parts with consistent layers. J Intell Manuf. https://doi. org/10.1007/s10845-020-01628-4

111. Cho G, Asano H, Kon M (2019) Object-forming machine, crosssection measurement apparatus, and cross-section measurement method. US Patent 10618220B2

112. Jin Z, Zhang Z, Gu GX (2019) Autonomous in-situ correction of fused deposition modeling printers using computer vision and deep learning. Manuf Lett 22:11-15. https://doi.org/10.1016/j. mfglet.2019.09.005

113. Baumann F, Roller D (2016) Vision based error detection for 3D printing processes. MATEC Web Conf. https://doi.org/10.1051/ matecconf/20165906003

114. Trinks S, Felden C (2019) Image mining for real time fault detection within the smart factory. 2019 IEEE 21st Conf Bus Inform (CBI):584-593. https://doi.org/10.1109/cbi.2019.00074

115. Trinks S, Felden C (2019) Image mining for real time quality assurance in rapid prototyping. 2019 IEEE Int Conf Big Data:3529-3534. https://doi.org/10.1109/BigData47090.2019. 9005514

116. Wang Y, Lin Y, Zhong RY et al (2019) IoT-enabled cloudbased additive manufacturing platform to support rapid product development. Int J Prod Res 57:3975-3991. https://doi.org/10. 1080/00207543.2018.1516905

117. Capri S, Asbury RC (2019) Image-based monitoring and feedback system for three-dimensional printing. US Patent 10265911B1

118. Chen P-Y, Lin W-T (2015) Three dimensional printing apparatus and method for detecting printing anomaly. US Patent 9632037B2

119. Straub J (2015) Initial work on the characterization of additive manufacturing (3D Printing) using software image Analysis. Machines 3:55-71. https://doi.org/10.3390/machines3020055

120. Straub J (2015) Characterization of 3D printing output using an optical sensing system. Proc SPIE Dimens Opt Metrol Insp Pract Appl IV. https://doi.org/10.1117/12.2177647

121. Straub J (2016) Alignment issues, correlation techniques and their assessment for a visible light imaging-based 3D printer quality control system. Proc SPIE Image Sens Technol Mater 
Devices Syst Appl III:9854. https://doi.org/10.1117/12.22280 81

122. Straub J (2016) Automated testing and quality assurance of $3 d$ printing / 3D printed hardware: assessment for quality assurance and cybersecurity purposes. 2016 IEEE AUTOTESTCON. https://doi.org/10.1109/AUTEST.2016.7589613

123. Straub J (2016) Characterization of internal geometry / covered surface defects with a visible light sensing system. Proc SPIE Image Sens Technol Mater Devices Syst Appl III:9854. https:// doi.org/10.1117/12.2227802

124. Straub J (2017) An approach to detecting deliberately introduced defects and micro-defects in 3D printed objects. Proc SPIE: Dimens Opt Metrol Insp Pract Appl VI. https://doi.org/10.1117/ 12.2264588

125. Straub J (2017) A combined system for 3D printing cybersecurity. Proc SPIE Dimens Opt Metrol Insp Pract Appl VI. https:// doi.org/10.1117/12.2264583

126. Straub J (2017) Physical security and cyber security issues and human error prevention for 3D printed objects: Detecting the use of an incorrect printing material. Proc SPIE Dimens Opt Metrol Insp Pract Appl VI. https://doi.org/10.1117/12.2264578

127. Ceruti A, Liverani A, Bombardi T (2017) Augmented vision and interactive monitoring in $3 \mathrm{D}$ printing process. Int $\mathrm{J}$ Interact Des Manuf 11:385-395. https://doi.org/10.1007/s12008-016-0347-y

128. Lyngby RA, Wilm J, Eiríksson ER et al (2017) In-line 3D print failure detection using computer vision. Joint Special Interest Group meeting between euspen and ASPE: Dimensional Accuracy and Surface Finish in Additive Manufacturing

129. Johnson A, Zarezadeh H, Han X et al (2016) Establishing inprocess inspection requirements for material extrusion additive manufacturing. Fraunhofer Direct Digit Manuf Conf

130. Oleff A, Küster B, Stonis M et al (2020) Optische Qualitätsprüfung für die additive Materialextrusion. ZWF 115:52-56. https:// doi.org/10.3139/104.112228

131. He K, Zhang Q, Hong Y (2019) Profile monitoring based quality control method for fused deposition modeling process. J Intell Manuf 30:947-958. https://doi.org/10.1007/s10845-018-1424-9

132. Wu Y, He K, Zhou X et al (2017) Machine Vision based Statistical Process Control in Fused Deposition Modeling. 2017 12th IEEE Conf Ind Electron Appl (ICIEA):936-941. https://doi.org/ 10.1109/ICIEA.2017.8282973

133. Wu Y, He K, Hu H et al (2019) Process Monitoring of Fused Deposition Modeling through Profile Control. 2018 IEEE Int Conf Cyborg Bionic Syst (CBS):936-941. https://doi.org/10. 1109/CBS.2018.8612192

134. Delli U, Chang S (2018) Automated Process Monitoring in 3D Printing Using Supervised Machine Learning. Procedia Manuf 26:865-870. https://doi.org/10.1016/j.promfg.2018.07.111

135. Engle J, Nguyen R, Buah K et al (2019) Reducing computer visualization errors for in-process monitoring of additive manufacturing systems using smart lighting and colorization system. Proc 30th Annu Int Solid Free Fabr Symp:1482-1496

136. Peek GA (2016) Printer monitoring. US Patent 9514397B2

137. Perez AA, Haid CM, Doll MP et al (2018) Automatic process control of additive manufacturing device. US Patent 10427348B2

138. Cheverton MA, Allen Nafis C, Tait RW et al (2015) Operational performance assessment of additive manufacturing. US Patent 9724876B2

139. Fastowicz J, Bąk D, Mazurek P et al (2018) Estimation of geometrical deformations of 3D prints using local cross-correlation and Monte Carlo Sampling. In: Choraś M, Choraś RS (eds) Image Processing and Communications Challenges 9, vol 681. Springer, Cham, pp 67-74

140. Fastowicz J, Bąk D, Mazurek P et al (2018) Quality assessment of 3D Printed surfaces in Fourier Domain. In: Choraś M, Choraś
RS (eds) Image Processing and Communications Challenges 9, vol 681. Springer, Cham, pp 75-81

141. Fastowicz J, Okarma K (2016) Texture based quality assessment of 3D prints for different lighting conditions. In: Chmielewski LJ, Datta A, Kozera R et al (eds) Computer Vision and Graphics, vol 9972. Springer, Cham, pp 17-28

142. Fastowicz J, Okarma K (2017) Entropy based surface quality assessment of 3D Prints. In: Silhavy R, Senkerik R, Kominkova Oplatkova $Z$ et al (eds) Artificial Intelligence Trends in Intelligent Systems. Springer, Cham, pp 404-413

143. Fastowicz J, Okarma K (2018) Fast quality assessment of 3D printed surfaces based on structural similarity of image regions. 2018 Int Interdiscip PhD Workshop (IIPhDW):401-406. https:// doi.org/10.1109/IIPHDW.2018.8388399

144. Fastowicz J, Okarma K (2019) Automatic colour independent quality evaluation of 3D printed flat surfaces based on CLAHE and Hough Transform. In: Choraś M, Choraś RS (eds) Image Processing and Communications Challenges 10, vol 892. Springer, Cham, pp 123-131

145. Lech P, Fastowicz J, Okarma K (2018) Quality evaluation of 3D printed surfaces based on HOG features. In: Chmielewski LJ, Kozera R, Orłowski A et al (eds) Computer Vision and Graphics. Springer, Cham, pp 199-208

146. Okarma K, Fastowicz J (2016) No-reference quality assessment of 3D prints based on the GLCM analysis. 2016 21st Int Conf Methods Model Autom Robot:788-793. https://doi.org/10.1109/ MMAR.2016.7575237

147. Okarma K, Fastowicz J (2017) Quality assessment of 3D prints based on feature similarity metrics. In: Choraś RS (ed) Image Processing and Communications Challenges 8. Springer, Cham, pp 104-111

148. Fastowicz J, Okarma K (2019) Quality Assessment of Photographed 3D printed flat surfaces using Hough transform and histogram equalization. J Univers Comput Sci 25:707-717. https:// doi.org/10.3217/jucs-025-06-0701

149. Okarma K, Fastowicz J (2018) Color Independent Quality Assessment of 3D Printed Surfaces Based on Image Entropy. Proc 2017 10th Int Conf Comput Recognit Syst (CORES):308315. https://doi.org/10.1007/978-3-319-59162-9

150. Okarma K, Fastowicz J (2019) Adaptation of full-reference image quality assessment methods for automatic visual evaluation of the surface quality of 3D Prints. Elektron ir Elektrotechnika 25:57-62. https://doi.org/10.5755/j01.eie.25.5.24357

151. Okarma K, Fastowicz J (2020) Computer vision methods for non-destructive quality assessment in additive manufacturing. In: Burduk R, Kurzynski M, Wozniak M (eds) Progress in Computer Recognition Systems, vol 977. Springer, Cham, pp 11-20

152. Okarma K, Fastowicz J (2020) Improved quality assessment of colour surfaces for additive manufacturing based on image entropy. Pattern Anal Appl 23:1035-1047. https://doi.org/10. 1007/s10044-020-00865-w

153. Okarma K, Fastowicz J, Tecław M (2016) Application of structural similarity based metrics for quality assessment of 3D prints. In: Chmielewski LJ, Datta A, Kozera R et al (eds) Computer Vision and Graphics. Springer, pp 244-252

154. Fastowicz J, Grudziński M, Tecław M et al (2019) Objective 3D printed surface quality assessment based on entropy of depth maps. Entropy. https://doi.org/10.3390/e21010097

155. Fastowicz J, Lech P, Okarma K (2020) Combined metrics for quality assessment of 3D printed surfaces for aesthetic purposes: Towards Higher Accordance with Subjective Evaluations. In: Krzhizhanovskaya VV, Závodszky G, Lees MH et al (eds) Computational Science - ICCS 2020: Lecture Notes in Computer Science, vol 12143. Springer, Cham, pp 326-339 
156. Blanco D, Fernandez P, Noriega A et al (2020) Layer contour verification in additive manufacturing by means of commercial flatbed scanners. Sensors. https://doi.org/10.3390/s20010001

157. Greeff GP, Schilling M (2017) Closed loop control of slippage during filament transport in molten material extrusion. Addit Manuf 14:31-38. https://doi.org/10.1016/j.addma.2016.12.005

158. Greeff GP, Schilling M (2017) Comparing retraction methods with volumetric exit flow measurement in molten material extrusion. Joint Special Interest Group meeting between euspen and ASPE: Dimensional Accuracy and Surface Finish in Additive Manufacturing:70-74

159. Basile V, Modica F, Fontana G et al (2020) Improvements in accuracy of fused deposition modeling via integration of lowcost on-board vision systems. J Micro Nanomanuf. https://doi. org/10.1115/1.4046038

160. Liu C, Law ACC, Roberson D et al (2019) Image analysis-based closed loop quality control for additive manufacturing with fused filament fabrication. J Manuf Syst 51:75-86. https://doi.org/10. 1016/j.jmsy.2019.04.002

161. Liu C, Roberson D, Kong Z (2017) Textural analysis-based online closed-loop quality control for additive manufacturing processes. Proc 2017 Ind Syst Eng Conf:1127-1132

162. Liu C (2019) Smart additive manufacturing using advanced data analytics and closed loop control. Dissertation, Virginia Polytechnic Institute and State University

163. Batchelder JS, Bosveld MS (2014) Encoded consumable materials and sensor assemblies for use in additive manufacturing systems. US Patent 9855679B2

164. Li N, Link G, Jelonnek J (2020) 3D microwave printing temperature control of continuous carbon fiber reinforced composites. Compos Sci Technol. https://doi.org/10.1016/j.compscitech. 2019.107939

165. Malekipour E, Attoye S, El-Mounayri H (2018) Investigation of layer based thermal behavior in fused deposition modeling process by infrared thermography. Procedia Manuf 26:1014-1022. https://doi.org/10.1016/j.promfg.2018.07.133

166. Lu Y, Wang Y (2018) Monitoring temperature in additive manufacturing with physics-based compressive sensing. J Manuf Syst 48:60-70. https://doi.org/10.1016/j.jmsy.2018.05.010

167. Lu Y, Wang Y (2019) An improvement of physics based compressive sensing with domain decomposition to monitor temperature in fused filament fabrication process. Proc ASME 2019 14th Int Manuf Sci Eng Conf. https://doi.org/10.1115/MSEC2 019-2899

168. Lu Y, Wang Y (2019) An efficient transient temperature monitoring of fused filament fabrication process with physics-based compressive sensing. IISE Trans 51:168-180. https://doi.org/ 10.1080/24725854.2018.1499054

169. He K, Wang H, Hu H (2018) Approach to online defect monitoring in fused deposition modeling based on the variation of the temperature field. Complexity. https://doi.org/10.1155/ 2018/3426928

170. Hu H, He K, Zhong T et al (2019) Fault diagnosis of FDM process based on support vector machine (SVM). Rapid Prototyp J 26:330-248. https://doi.org/10.1108/RPJ-05-2019-0121

171. Ferraris E, Zhang J, van Hooreweder B (2019) Thermography based in-process monitoring of Fused Filament Fabrication of polymeric parts. CIRP Ann Manuf Technol 68:213-216. https://doi.org/10.1016/j.cirp.2019.04.123

172. Pooladvand K, Salerni AD, Furlong C (2019) In-situ thermal monitoring of printed components during rapid prototyping by fused deposition modeling. Proc 2019 Annu Conf Exp Appl Mech 95:131-140. https://doi.org/10.1007/978-3-030-300982_20

173. Bartolai J, Simon TR, Xie R (2016) Predicting strength of thermoplastic polymer parts produced using additive manufacturing. Proc 27th Annu Int Solid Free Fabr Symp:951-963

174. Bartolai J, Simpson TW, Xie R (2018) Predicting strength of additively manufactured thermoplastic polymer parts produced using material extrusion. Rapid Prototyp J 24:321-332. https:// doi.org/10.1108/RPJ-02-2017-0026

175. Hsu S-H, Chen W-Y (2018) System and method for detecting printing filament for three dimensional printing. US Patent 10042350B2

176. Pollard D, Ward C, Herrmann G et al (2017) Filament Temperature Dynamics in Fused Deposition Modelling and Outlook for Control. Procedia Manuf 11:536-544. https://doi.org/10. 1016/j.promfg.2017.07.147

177. Pollard D (2019) Improved thermal control and mechanical property evaluation for multi-dimensional fused filament fabrication of sandwich cores. Dissertation, University of Bristol

178. Müller M, Wings E (2016) An architecture for hybrid manufacturing combining 3D printing and $\mathrm{CNC}$ machining. Int J Manuf Mater Mech Eng. https://doi.org/10.1155/2016/8609108

179. Kousiatza C, Chatzidai N, Karalekas D (2017) Temperature mapping of 3D printed polymer plates: Experimental and numerical study. Sensors. https://doi.org/10.3390/s17030456

180. Miao G, Hsieh S-J, Segura JA et al (2019) Cyber-physical system for thermal stress prevention in 3D printing process. Int J Adv Manuf Technol 100:553-567. https://doi.org/10.1007/ s00170-018-2667-5

181. Tlegenov Y, Wong YS, Hong GS (2017) A dynamic model for nozzle clog monitoring in fused deposition modelling. Rapid Prototyp J 23:391-400. https://doi.org/10.1108/ RPJ-04-2016-0054

182. Tlegenov Y, Hong GS, Lu WF (2018) Nozzle condition monitoring in 3D printing. Robot Comput Integr Manuf 54:45-55. https://doi.org/10.1016/j.rcim.2018.05.010

183. Li B, Zhang L, Ren L et al (2019) 3D printing fault detection based on process data. Proc 2018 Chin Intell Syst Conf:385396. https://doi.org/10.1007/978-981-13-2291-4_38

184. Liao J, Shen Z, Xiong G et al (2019) Preliminary study on fault diagnosis and intelligent learning of fused deposition modeling (FDM) 3D Printer. 14th IEEE Conf Ind Electron Appl (ICIEA):2098-2102. https://doi.org/10.1109/ICIEA.2019.88343 76

185. Li Y, Zhao W, Li Q et al (2019) In-situ monitoring and diagnosing for fused filament fabrication process based on vibration sensors. Sensors. https://doi.org/10.3390/s19112589

186. Zhao X, Lian Q, He Z et al (2020) Region-based online flaw detection of 3D printing via fringe projection. Meas Sci Technol. https://doi.org/10.1088/1361-6501/ab524b

187. Ye Z, Liu C, Tian W et al (2020) A deep learning approach for the identification of small process shifts in additive manufacturing using 3D Point Clouds. Procedia Manuf 48:770-775. https:// doi.org/10.1016/j.promfg.2020.05.112

188. Preissler M, Broghammer J, Rosenberger M et al (2018) Inline process monitoring method for geometrical characteristics in additive manufacturing. J Phys Conf Ser. https://doi.org/10.1088/ 1742-6596/1044/1/012035

189. Preissler M, Zhang C, Notni G (2018) Approach for optical innervolumetric 3-dimensional data acquisition. J Phys Conf Ser. https://doi.org/10.1088/1742-6596/1065/3/032005

190. Preissler M, Zhang C, Rosenberger M et al (2018) Approach for process control in additive manufacturing through layer-wise analysis with 3-dimensional pointcloud information. 2018 Digit Image Comput.: Tech Appl (DICTA):304-309. https://doi.org/ 10.1109/DICTA.2018.8615803

191. Preissler M, Notni G (2019) Feature detection in unorganized pointclouds. Proc SPIE: Photonics Educ 11144:15. https://doi. org/10.1117/12.2530809 
192. Putman MC, Pinskiy V, Williams J et al (2019) Systems, methods, and media for artificial intelligence feedback control in additive manufacturing. US Patent 10518480B2

193. Holzmond O, Li X (2017) In situ real time defect detection of 3D printed parts. Addit Manuf 17:135-142. https://doi.org/10. 1016/j.addma.2017.08.003

194. Gupta L, Khatakalle S (2017) Facilitating intelligent calibration and efficeint performance of three-dimensional printers. US Patent 20170057170A1

195. Lin W, Shen H, Fu J et al (2019) Online quality monitoring in material extrusion additive manufacturing processes based on laser scanning technology. Precis Eng 60:76-84. https://doi.org/ 10.1016/j.precisioneng.2019.06.004

196. Faes M, Abbeloos W, Vogeler F et al (2014) Process monitoring of extrusion based 3D printing via laser scanning. Int Conf Polym Moulds Innovations (PMI) 6:363-367. https://doi.org/10. 13140/2.1.5175.0081

197. Sohnius F, Schlegel P, Ellerich M et al (2019) Data-driven prediction of surface quality in fused deposition modeling using machine learning. In: Wulfsberg JP, Hintze W, Behrens B-A (eds) Production at the leading edge of technology. Springer, Berlin, pp 473-481

198. Gunther SM (2019) Quality control of additive manufactured parts. US Patent 10183329B2

199. Yang Z, Jin L, Yan Y et al (2018) Filament breakage monitoring in fused deposition modeling using acoustic emission technique. Sensors. https://doi.org/10.3390/s18030749

200. Lotrakul P, San-Um W, Takahashi M (2017) The monitoring of three-dimensional printer filament feeding process using an acoustic emission sensor. In: Matsumoto M, Masui K, Fukushige $\mathrm{S}$ et al (eds) Sustainability Through Innovation in Product Life Cycle Design. Springer, Singapore, pp 499-511

201. Liu J, Hu Y, Wu B et al (2018) An improved fault diagnosis approach for FDM process with acoustic emission. J Manuf Process 35:570-579. https://doi.org/10.1016/j.jmapro.2018.08.038

202. Wu H, Wang Y, Yu Z (2016) In situ monitoring of FDM machine condition via acoustic emission. Int J Adv Manuf Technol 84:1483-1495. https://doi.org/10.1007/s00170-015-7809-4

203. Wu H, Yu Z, Wang Y (2017) Real-time FDM machine condition monitoring and diagnosis based on acoustic emission and hidden semi-Markov model. Int J Adv Manuf Technol 90:2027-2036. https://doi.org/10.1007/s00170-016-9548-6

204. Li F, Yu Z, Yang Z et al (2019) Real-time distortion monitoring during fused deposition modeling via acoustic emission. Struct Health Monit 19:412-423. https://doi.org/10.1177/1475921719 849700

205. Wu H, Yu Z, Wang Y (2016) A new approach for online monitoring of additive manufacturing based on acoustic emission. Proc ASME 2016 Manuf Sci Eng Conf 3. https://doi.org/10. 1115/MSEC20168551

206. Wu H, Yu Z, Wang Y (2019) Experimental study of the process failure diagnosis in additive manufacturing based on acoustic emission. Measurement 136:445-453. https://doi.org/10. 1016/j.measurement.2018.12.067

207. Chhetri SR, Canedo A, Al Faruque MA (2016) Kcad: kinetic cyber-attack detection method for cyber-physical additive manufacturing systems. IEEE/ACM Int Conf Computer-Aided Des (ICCAD). https://doi.org/10.1145/2966986.2967050

208. Bayens C, Le T, Garcia L et al (2017) See No Evil, Hear No Evil, Feel No Evil, Print No Evil? Malicious Fill Patterns Detection in Additive Manufacturing. Proc 26th USENIX Secur Symp:1181-1198

209. Becker P, Roth C, Roennau A et al (2020) Acoustic Anomaly Detection in Additive Manufacturing with Long Short-Term Memory Neural Networks. IEEE 7th Int Conf Ind Eng Appl
(ICIEA):921-926. https://doi.org/10.1109/ICIEA49774.2020. 9102002

210. Belikovetsky S, Solewicz YA, Yampolskiy M et al (2019) Digital Audio Signature for 3D Printing Integrity. IEEE Trans Inf Forensics Secur 14:1127-1141. https://doi.org/10.1109/TIFS. 2018.2851584

211. Kim C, Espalin D, Cuaron A et al (2015) A study to detect a material deposition status in fused deposition modeling technology. IEEE Int Conf Adv Intell Mechatron (AIM):779-783. https://doi.org/10.1109/AIM.2015.7222632

212. Kim C, Espalin D, Cuaron A et al (2018) Unobtrusive in situ diagnostics of filament-fed material extrusion additive Manufacturing. IEEE Trans Compon Packag Manuf Technol 8:1469-1476. https://doi.org/10.1109/TCPMT.2018.2847566

213. Kim CY, Espalin D, MacDonald E et al (2017) In-situ diagnostics and control method and system for material extrusion 3d printing US20170315526A1

214. Tlegenov Y, Lu WF, Hong GS (2019) A dynamic model for current-based nozzle condition monitoring in fused deposition modelling. Prog Addit Manuf 4:211-223. https://doi.org/10. 1007/s40964-019-00089-3

215. Gatlin J, Belikovetsky S, Moore SB et al (2019) Detecting sabotage attacks in additive manufacturing using actuator power signatures. IEEE Access 7:133421-133432. https://doi.org/10. 1109/ACCESS.2019.2928005

216. Chung DDL, Somaratna S (2017) Laboratory simulation of capacitance-based layer-by-layer monitoring of three-dimensional printing. Sens Actuators A Phys 268:101-109. https:// doi.org/10.1016/j.sna.2017.10.061

217. Chung DDL (2019) Systems and method for monitoring threedimensional printing US10449721B2

218. Shahriar MR, Sunny SMNA, Liu X et al (2018) MTComm based virtualization and integration of physical machine operations with digital-twins in cyber-physical manufacturing cloud. 5th IEEE Int Conf Cyber Secur Cloud Comput (CSCloud):46-51. https://doi.org/10.1109/CSCloud/EdgeC om.2018.00018

219. Kemperle A, Gelman F, Schmehl PJ (2016) Three-dimensional printer with force detection. US Patent 10556381B2

220. Batchelder JS, Swanson WJ, Johnson KC (2015) Additive manufacturing system and process with material flow feedback control. US Patent 10201931B2

221. Economidou SN, Karalekas D (2016) Optical sensor-based measurements of thermal expansion coefficient in additive manufacturing. Polym Test 51:117-121. https://doi.org/10. 1016/j.polymertesting.2016.03.001

222. Economidou SN, Karalekas D (2018) Characterization of fused deposition modeling polymeric structures using embedded fiber Bragg grating sensors. In: Zhang J, Jung Y-G (eds) Additive Manufacturing. Butterworth-Heinemann, pp 163-180

223. Kantaros A, Giannatsis D, Karalekas D (2013) A novel strategy for the incorporation of optical sensors in FDM parts. Int Conf Adv Manuf Eng Technol (NewTech):163-170

224. Kantaros A, Karalekas D (2013) Fiber Bragg grating based investigation of residual strains in ABS parts fabricated by fused deposition modeling process. Mater Des 50:44-50. https://doi.org/10. 1016/j.matdes.2013.02.067

225. Kantaros A, Karalekas D (2014) FBG based in situ characterization of residual strains in FDM process. In: Rossi M, Sasso M, Connesson N (eds) Residual Stress, Thermomechanics \& Infrared Imaging, Hybrid Techniques and Inverse Problems, Volume 8 , Springer, Cham

226. Kousiatza C, Karalekas D (2020) Experimental study of fabrication-induced residual strains and distortions in polymeric square plates built using fused deposition modeling process. Mater Des Process Commun. https://doi.org/10.1002/mdp2.149 
227. Wang M, Liu L, Ren Y et al (2020) Investigation of heated nozzle temperature in ABS Specimens fabricated based on fiber bragg grating during fused deposition modeling process. Integr Ferroelectr 208:177-180. https://doi.org/10.1080/10584587.2020. 1728729

228. Wang S, Lasn K, Elverum CW et al (2020) Novel in-situ residual strain measurements in additive manufacturing specimens by using the Optical Backscatter Reflectometry. Addit Manuf. https://doi.org/10.1016/j.addma.2020.101040

229. Rooney S, Pochiraju K (2019) Simulations of Online NonDestructive Acoustic Diagnosis of 3D-Printed Parts Using AirCoupled Ultrasonic Transducers. Int Mech Eng Congr Expos (IMECE2019). https://doi.org/10.1115/IMECE2019-11101

230. Xu X, Vallabh CKP, Cleland ZJ et al (2017) Phononic crystal artifacts for real-time in situ quality monitoring in additive manufacturing. J Manuf Sci Eng. https://doi.org/10.1115/1.4036908

231. Xu X, Vallabh CKP, Krishnan A et al (2019) In-process thread orientation monitoring in additive manufacturing. 3D Print Addit Manuf 6:21-30. https://doi.org/10.1089/3dp.2018.0135

232. Cummings I, Hillstrom E, Newton R et al (2016) In-process ultrasonic inspection of additive manufactured parts. In: Mains M (ed) Topics in Modal Analysis \& Testing, vol 10. vol 10. Springer, Cham, pp 235-247

233. Cummings IT, Bax ME, Fuller IJ et al (2017) A framework for additive manufacturing process monitoring \& control. In: Mains M, Blough JR (eds) Topics in Modal Analysis \& Testing, vol 10. 10B. Springer, Cham, pp 137-146

234. Koskelo EC, Flynn EB, Shull PJ, Gyekenyesi AL, Yu T, Wu HF (2016) Scanning laser ultrasound and wavenumber spectroscopy for in-process inspection of additively manufactured parts. Proc SPIE Nondestruct Charact Monit Adv Mater Aerosp Civ Infrastruct. https://doi.org/10.1117/12.2222130

235. Heras ES, Haro FB, del Burgo J, de Agustín M (2016) Development of a filament auto-detection system for fused deposition modelling 3D printers. Técnica Industrial 315:30-36

236. Soriano Heras E, Blaya Haro F, del Burgo, de Agustín José M. et al (2018) Filament advance detection sensor for fused deposition modelling 3D printers. Sensors. https://doi.org/10.3390/ s18051495

237. Weiss B, Storti D, Ganter M (2015) Low-cost closed-loop control of a 3D printer gantry. Rapid Prototyp J 21:482-490. https://doi. org/10.1108/RPJ-09-2014-0108

238. Li L, McGuan R, Kavehpour P et al (2018) Precision Enhancement of 3D Printing via In Situ Metrology. Proc 29th Annu Int Solid Free Fabr Symp:251-260

239. Li J, Xie H, Ma K (2019) In-situ monitoring of the deformation during Fused Deposition Modeling process using CGS method. Polym Test 76:166-172. https://doi.org/10.1016/j.polymertes ting.2019.03.030

240. Bhavsar P, Sharma B, Moscoso-Kingsley W et al (2020) Detecting first layer bond quality during FDM 3D printing using a discrete wavelet energy approach. Procedia Manuf 48:718-724. https://doi.org/10.1016/j.promfg.2020.05.104

241. Creuzer M, Fetter W (2015) Integrated measuring and additive manufacturing apparatus and method. US Patent 2015/0174828A1

242. Fieber L, Bukhari SS, Wu Y et al (2020) In-line measurement of the dielectric permittivity of materials during additive manufacturing and 3D data reconstruction. Addit Manuf. https:// doi.org/10.1016/j.addma.2019.101010

243. Batchelder JS (2014) Additive Manufacturing System and Method for Printing Three-Dimensional Parts Using Velocimetry. US Patent 9527240B2

244. Hampel B, Tollkühn M, Schilling M (2019) Anisotropic magnetoresistive sensors for control of additive manufacturing machines. tm - Tech Mess 86:609-618. https://doi.org/10. 1515/teme-2019-0016

245. Reese R, Bheda H, Mondesir W (2016) Method to monitor additive manufacturing process for detection and in-situ correction of defects. US Patent 10421267B2

246. Falcetelli F, Di Sante R, Troiani E (2021) Strategies for embedding optical fiber sensors in additive manufacturing structures. In: Rizzo P, Milazzo A (eds) European Workshop on Structural Health Monitoring. Springer, Cham, pp 362-371

247. Anderegg DA, Bryant HA, Ruffin DC et al (2019) In-situ monitoring of polymer flow temperature and pressure in extrusion based additive manufacturing. Addit Manuf 26:76-83. https:// doi.org/10.1016/j.addma.2019.01.002

248. Yoon J, He D, van Hecke B (2014) A PHM approach to additive manufacturing equipment health monitoring, fault diagnosis, and quality control. Proc Annu Conf Progn Heal Manag Soc. https://doi.org/10.36001/phmconf.2014.v6i1.2338

249. Kousiatza C, Karalekas D (2015) Real-time process monitoring of 3D printed multilayered structures using optical fiber bragg grating sensors. 20th Int Conf Compos Mater (ICCM) 2015-July

250. Kousiatza C, Karalekas D (2016) In-situ monitoring of strain and temperature distributions during fused deposition modeling process. Mater Des 97:400-406. https://doi.org/10.1016/j.matdes. 2016.02.099

251. Kousiatza C, Tzetzis D, Karalekas D (2019) In-situ characterization of 3D printed continuous fiber reinforced composites: A methodological study using fiber Bragg grating sensors. Compos Sci Technol 174:134-141. https://doi.org/10.1016/j.compscitech. 2019.02.008

252. Balta EC, Tilbury DM, Barton K (2019) A digital twin framework for performance monitoring and anomaly detection in fused deposition modeling. IEEE 15th Int Conf Autom Sci Eng (CASE):823-829. https://doi.org/10.1109/COASE.2019.88431 66

253. LADANYI R (2017) Method and system for 3d printer with improved performance and $3 \mathrm{~d}$ printer employing same. US Patent 2017/0312987A1

254. Chhetri SR, Faezi S, Canedo A et al (2019) QUILT: Quality Inference from Living Digital Twins in IoT-Enabled Manufacturing Systems. Proc Int Conf Internet Thing Des Implement:237-248. https://doi.org/10.1145/3302505.3310085

255. Yu S-Y, Malawade AV, Chhetri SR et al (2020) Sabotage attack detection for additive manufacturing systems. IEEE Access 8:27218-27231. https://doi.org/10.1109/ACCESS.2020.2971947

256. Wang L, Xu M'e, Si P et al (2019) On-line monitoring method and system for three-dimensional printing. US Patent 10649439B2

257. Sinclair JM (2017) Verification and adjustment systems and methods for additive manufacturing. US Patent 9912915B2

258. Haro FB, de Agustín Del Burgo JM, D’Amato R et al (2019) Monitoring an Analysis of Perturbations in Fusion Deposition Modelling (FDM) Processes for the Use of Biomaterials. J Med Syst 43:109. https://doi.org/10.1007/s10916-019-1236-2

259. Del Burgo, J. M. d. A., D’Amato R, Méndez JAJ et al (2019) Real time analysis of the filament for FDM 3D printers. Proc 7th Int Conf Technol Ecosyst Enhancing Multicult:354-360. https://doi. org/10.1145/3362789.3362818

260. Coogan TJ, Kazmer DO (2019) In-line rheological monitoring of fused deposition modeling. J Rheol 63:141-155. https://doi. org/10.1122/1.5054648

261. Coogan TJ, Kazmer DO (2019) Modeling of interlayer contact and contact pressure during fused filament fabrication. J Rheol 63:655-672. https://doi.org/10.1122/1.5093033 
262. Coogan TJ, Kazmer DO (2020) Prediction of interlayer strength in material extrusion additive manufacturing. Addit Manuf 35:101368. https://doi.org/10.1016/j.addma.2020.101368

263. Stanisavljevic D, Cemernek D, Gursch H et al (2019) Detection of interferences in an additive manufacturing process: an experimental study integrating methods of feature selection and machine learning. Int J Prod Res 58:2862-2884. https://doi.org/ 10.1080/00207543.2019.1694719

264. Rusu CC, Belaid S, Mistodie LR et al (2019) Condition-based maintenance model for the optimization of smart manufacturing processes. Ann "Dunarea de Jos" Univ Galati, Fascicle XII, Weld Equip Technol 30:34-42. https://doi.org/10.35219/awet.2019.05

265. Nagar SV, Chandrashekar AC, Suvarna M (2020) Optimized additive manufacturing technology using digital twins and cyber physical systems. In: Auer ME, Ram BK (eds) Cyber-physical Systems and Digital Twins. Springer, Cham, pp 65-73

266. Kim JS, Lee CS, Kim S-M et al (2018) Development of datadriven in-situ monitoring and diagnosis system of fused deposition modeling (FDM) process based on support vector machine algorithm. Int J Precis Eng Manuf.-Green Technol 5:479-486. https://doi.org/10.1007/s40684-018-0051-4

267. Li Z, Zhang Z, Shi J et al (2019) Prediction of surface roughness in extrusion-based additive manufacturing with machine learning. Robot Comput Integr Manuf 57:488-495. https://doi.org/10. 1016/j.rcim.2019.01.004

268. Blandon S, Amaya JC, Rojas AJ (2015) Development of a 3D printer and a supervision system towards the improvement of physical properties and surface finish of the printed parts. IEEE 2nd Colomb Conf Autom Control (CCAC). https://doi.org/10. 1109/CCAC.2015.7345179

269. Moretti M, Bianchi F, Senin N (2020) Towards the development of a smart fused filament fabrication system using multi-sensor data fusion for in-process monitoring. Rapid Prototyp J 26:12491261. https://doi.org/10.1108/RPJ-06-2019-0167

270. Gao Y, Li B, Wang W et al (2018) Watching and safeguarding your 3D printer: online process monitoring against cyberphysical attacks. Proc ACM Interact Mob Wearable Ubiquitous Technol. https://doi.org/10.1145/3264918

271. Zhang J, Wang P, Gao RX (2018) Modeling of layer-wise additive manufacturing for part quality prediction. Procedia Manuf 16:155-162. https://doi.org/10.1016/j.promfg.2018.10.165

272. Zhang J, Wang P, Gao RX (2019) Deep learning-based tensile strength prediction in fused deposition modeling. Comput Ind 107:11-21. https://doi.org/10.1016/j.compind.2019.01.011

273. Schlegel P, Briele K, Schmitt RH (2019) Autonomous datadriven quality control in self-learning production systems. In:
Schmitt R, Schuh G (eds) Advances in Production Research. Springer, Cham, pp 679-689

274. Baumann F, Schön M, Eichhoff J et al (2016) Concept development of a sensor array for 3D printer. Procedia CIRP 51:24-31. https://doi.org/10.1016/j.procir.2016.05.041

275. Nam J, Jo N, Kim JS et al (2020) Development of a health monitoring and diagnosis framework for fused deposition modeling process based on a machine learning algorithm. Proc Inst Mech Eng B J Eng Manuf 234:324-332. https://doi.org/10.1177/09544 05419855224

276. Rao PK, Liu J, Roberson D et al (2015) Online Real-Time Quality Monitoring in Additive Manufacturing Processes Using Heterogeneous Sensors. J Manuf Sci Eng. https://doi.org/10.1115/1. 4029823

277. Bastani K, Rao PK, Kong Z (2016) An online sparse estimation-based classification approach for real-time monitoring in advanced manufacturing processes from heterogeneous sensor data. IIE Trans 48:579-598. https://doi.org/10.1080/0740817X. 2015.1122254

278. Sun H, Rao PK, Kong ZJ et al (2018) Functional quantitative and qualitative models for quality modeling in a fused deposition modeling process. IEEE Trans Autom Sci Eng 15:393-403. https://doi.org/10.1109/TASE.2017.2763609

279. MacNeish W, Gjovik E (2019) Apparatus, system and method of monitoring an additive manufacturing environment. US Patent 10406754B2

280. EN ISO 17296-3 (2016) Additive manufacturing - General principles - Part 3: Main characteristics and corresponding test methods

281. ISO/ASTM 52901 (2017) Additive manufacturing - General principles - Requirements for purchased AM parts

282. Farrar CR, Lieven NAJ (2007) Damage prognosis: the future of structural health monitoring. Philos Trans Royal Soc A Math Phys Eng Sci 365:623-632. https://doi.org/10.1098/rsta.2006. 1927

283. EN ISO 14638 (2015) Geometrical product specifications (GPS) - Matrix model

284. EN ISO 8785 (1999) Geometrical Product Specifications (GPS) - Surface imperfections - Terms, definitions and parameters

Publisher's Note Springer Nature remains neutral with regard to jurisdictional claims in published maps and institutional affiliations. 